doi: 10.32620/oikit.2021.91.01

УДК 629.7.01

О. 3. Двейрін, О.Г. Гребеніков, А.М. Гуменний, А.С. Чумак

\title{
Метод інтегрованого проектування носової частини фюзеляжу літака транспортної категорії
}

\author{
Національний аерокосмічний університет ім. М. Є. Жуковського «XАl»
}

Проведено аналіз вимог нормативно-технічної документації, особливостей конструкції і методів проектування фюзеляжу літаків транспортної категорії та виявлено необхідність актуалізації методів проектування та розрахунку характеристик фюзеляжу 3 використанням параметричних моделей і систем інтегрованого проектування CAD/CAM/CAE/PLM. Розроблено і теоретично обґрунтовано метод інтегрованого проектування фюзеляжу літаків транспортної категорії. У рамках запропонованого методу створено параметричні моделі майстер-геометрії, аеродинамічного обтікання і масово-інерційних характеристик фююеляжу з урахуванням особливостей конструкції літаків транспортної категорії.

Запропонований метод використано для дослідження впливу геометричних параметрів носової частини фюзеляжу (НЧФ) на аеродинамічні та масові характеристики фрюзеляжу літаків транспортної категорії, відзначено оперативність роботи 3 параметричними моделями.

Обґрунтовано вибір параметрів носової частини фюзеляжу у попередньому і ескізному проектуванні перспективного літака для місцевих повітряних ліній, що дозволило впровадити і апробувати придатність запропонованого методу для використання у створенні нової конкурентоспроможної авіаційної техніки.

Використання методу інтегрованого проектування фрюзеляжу для літака місцевих повітряних ліній дозволило визначити раціональну конфігурацію носової частини фюзеляжу і підвищити паливну ефективність літака на 6,4\%, знизити аеродинамічний опір фюзеляжу на $10 \%$, збільшити кут огляду із кабіни пілотів на $10 \%$ порівняно 3 конфігурацією попереднього проектування та забезпечити виконання вимог діючої нормативно-технічної документації, а також визначити масово-інерційні характеристики фюзеляжу і його частин і сформувати перелік обладнання кабіни пілотів, що забезпечить вимоги щодо безпеки польоту з урахуванням особливостей умов експлуатації та можливостей модифікації літака.

Розроблено конфрігурацію носової частини фююеляжу літака для місцевих повітряних ліній, що дозволяє забезпечити сучасні вимоги щодо обладнання та компонування кабіни пілотів, низький хвильовий опір фюзеляжу та високу аеродинамічну якість i паливну ефективність на крейсерському режимі польоту зі швидкістю до 850 км/год (M = 0,8). У результаті апробації з використанням інших методів і параметрів існуючих літаків підтверджено точність результатів, отриманих з використанням запропонованого методу на рівні $5 \%$.

Ключові слова: літак транспортної категорії; попереднє проектування; аеродинаміка; розрахунок маси; параметрична модель фрюзеляжу; кабіна пілотів, огляд, скінченноелементна модель.

Фюзеляж за призначенням і за функціональними ознаками являє собою один із найбільш складних агрегатів літака. Він служить для розміщення корисного навантаження, екіпажу обладнання, спорядження, а іноді силової установки і палива. Фюзеляж з'єднує в єдине ціле найважливіші агрегати літака: крило, оперення, шасі, силову установку [5, 6, 11]. Така фрункціональна складність зумовлює певні труднощі як вибору параметрів, розмірів і форми 
фрюзеляжу в процесі проектування, так і визначення зовнішніх навантажень, що діють на нього.

Фюзеляж складається 3 носової, середньої і хвостової частин. Конструктивно фюзеляж цивільного літака, як правило, являє собою тонкостінну каркасну конструкцію.

Метою статті $\epsilon$ розроблення методу інтегрованого проектування та комп'ютерного моделювання фюзеляжу цивільного літака за допомогою комп'ютерних інтегрованих систем CAD / CAM / CAE / PLM.

Вихідними даними при проектуванні $€$ означені в технічному завданні величина розрахункової дальності Lp польоту літака, маса корисного (комерційного) навантаження $\mathrm{m}_{\mathrm{H}}$, його габаритні розміри, значення швидкості $\mathrm{V}$ (максимальної і крейсерськоі), висота польоту $\mathrm{H}$, умови базування (клас аеродрому, довжина злітно-посадкової смуги), аеродинамічна якість на крейсерському режимі польоту, відносна маса конструкції фюзеляжу, ресурс фюзеляжу, габаритні розміри і маса вмісту фрюзеляжу (корисного навантаження, обладнання та спорядження), конструкційні матеріали, що застосовуються, сукупність критеріїв ефективності.

Відповідно до вихідних даних вибирають схему літака (рис. 1), визначають мінімальну злітну масу літака, оптимізують основні параметри літака, розробляють креслення загального вигляду літака, аеродинамічне, об'ємно-масове та конструктивно-силове компонування літака, розраховують центрування літака.

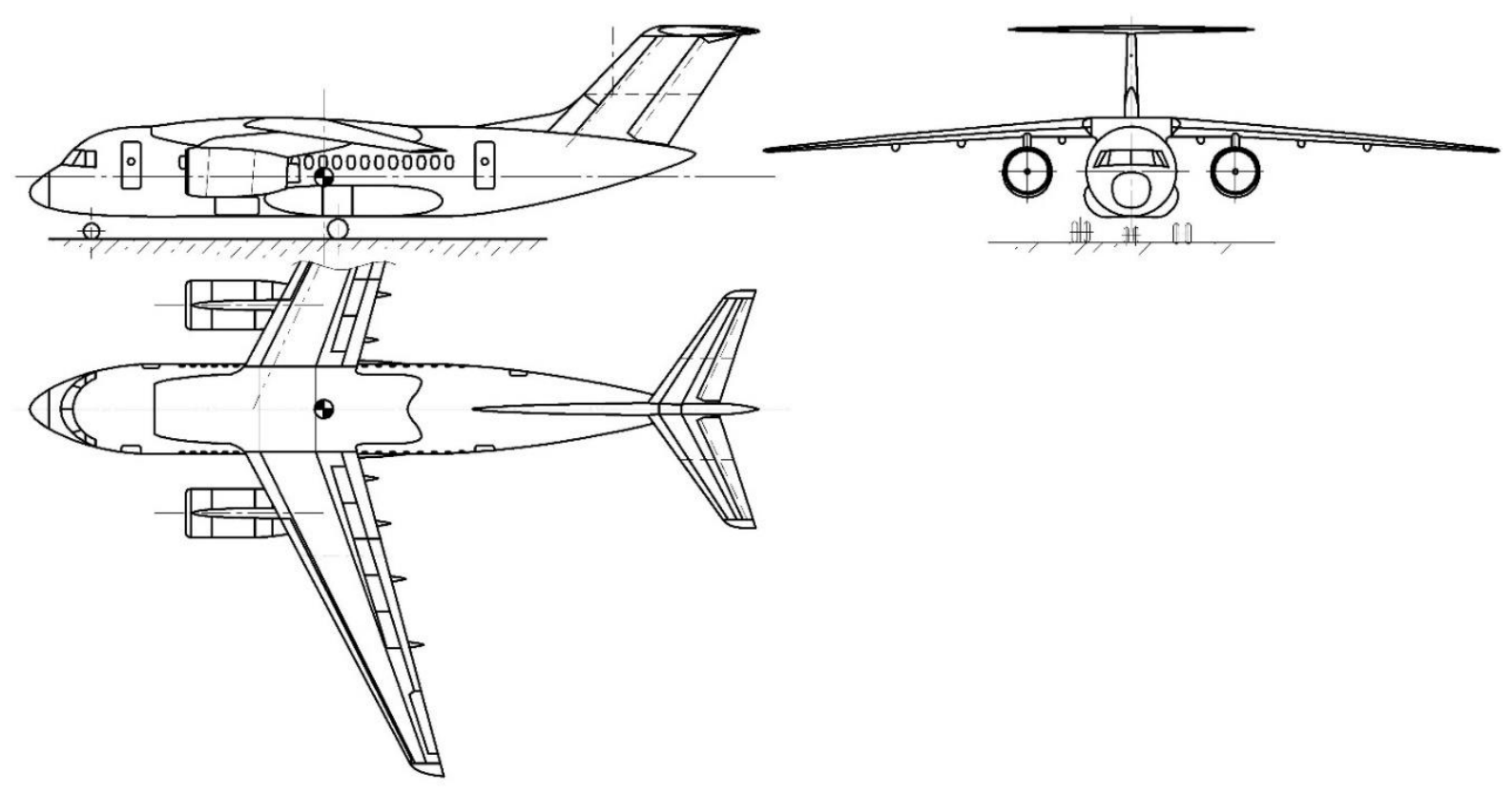

Рисунок 1 - Схема регіонального літака транспортної категорії

Зовнішня фрорма фюзеляжу визначається обрисами бічного вигляду, вигляду в плані носової і хвостової частин, а також формою поперечного перерізу. При виборі форми фрюзеляжу виходять перш за все з вимог аеродинаміки, експлуатації та забезпечення міцності конструкції при тривалій експлуатації. Визначення основних параметрів і характеристик фрюзеляжу слід проводити спільно з параметричними розрахунками інших частин літака. Весь 
цей розрахунок зручно представити у вигляді ітераційного процесу визначення злітної маси літака. Схема методу визначення параметрів фрюзеляжу показана на рис. 2.

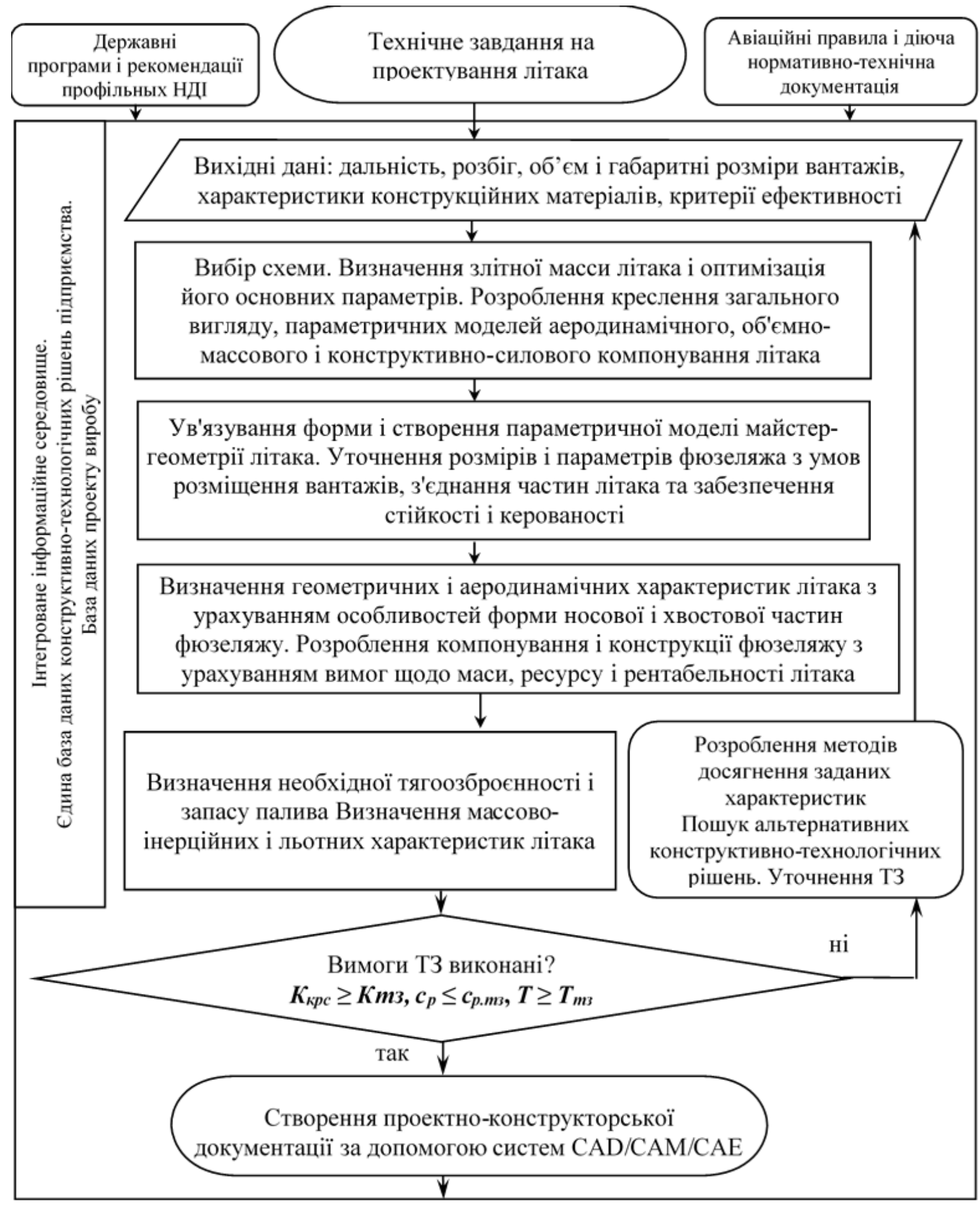

Рисунок 2 - Схема методу інтегрованого проектування фрюзеляжу літака транспортної категорії з урахуванням особливостей його носової частини 
Для віддалення хвильової кризи зі збільшенням швидкості польоту носова частина літака набуває загострених обрисів і значного подовження $[6,7]$. При цьому враховують фрорму ліхтаря кабіни екіпажу, що характеризується кутом $\varphi$ нахилу лобового скла. 3 ростом числа М польоту збільшують і кут $\varphi$.

Зменшенню опору літака сприяє застосування правила площ при проектуванні літаків з великими дозвуковими швидкостями і надзвукових літаків.

Форму поперечного перерізу фюзеляжу вибирають не тільки з точки зору аеродинаміки, але і з умов компонування, розміщення двигунів, екіпажу, пасажирів, обладнання, забезпечення міцності. Оптимальною фрормою поперечного перерізу вважають круглу. Така фрорма поперечного перерізу дозволяє отримати мінімальну масу конструкції, оскільки вона забезпечує обшивку найменшої товщини. Як різновид круглого перерізу розглядають перерізи, утворені поєднанням двох або кількох кіл частіше по вертикалі, але іноді і по горизонталі.

Діаметр фрюзеляжу $\mathrm{d}_{\Phi}$ вибирають з умов отримання мінімальної площі міделева перерізу $\mathrm{S}_{\Phi}$ і виконання найважливіших компонувальних вимог.

Для пасажирських і вантажних літаків мідель фрюзеляжу фрормують залежно від габаритних розмірів пасажирського салону або вантажної кабіни.

Розміри міделя фюзеляжу пасажирського літака визначають залежно від варіанта компонування (класу пасажирського салону), висоти пасажирського салону і висоти багажних відсіків, розташованих під ним .

У конструктивному відношенні найбільш оптимальною $€$ кругла фрорма поперечного перерізу фюзеляжу, оскільки в цьому випадку отримують високий рівень міцності при найменшій масі конструкції. Однак така фрорма перерізу часто виявляється неоптимальною виходячи 3 вимог компонування пасажирського салону і багажних приміщень, розташованих над підлогою останнього.

Для повного використання ширини фюзеляжу круглого перерізу потрібно розміщувати пасажирів так, щоб середина спинок крісел розташовувалася по горизонтальній осі фрюзеляжу. В цьому випадку висота салону стає нераціонально великою, а висота багажних приміщень - неприпустимо малою. Якщо спробувати підняти підлогу пасажирського салону для отримання необхідної висоти багажних приміщень, то зменшиться використовувана ширина пасажирського салону, а різке звуження бічних стін над крайніми кріслами створить враження пригніченості, затрудняється підхід до них. Усунути названі недоліки дозволяють такі конструктивні рішення:

- розміщення вантажних і багажних приміщень не під підлогою, а в носовій і хвостовій частинах фюзеляжу, що призведе до збільшення його довжини;

- вибір фрорми поперечного перерізу не круглої, а овальної або утвореної з двох і більше пересічних кіл.

Зазначені конструктивні рішення дозволяють забезпечити виконання компонувальних вимог і вимог до комфорту пасажирів і екіпажу, але вступають у протиріччя 3 характеристиками міцності, технологічними і виробничоекономічними вимогами. Так, при реалізації овальної форми поперечного перерізу для виконання міцності вимог необхідно посилити конструкцію фрюзеляжу на ділянці гермокабіни, а це призведе до збільшення маси конструкції планера літака. Посилення конструкції пов'язано з деформаціями фрюзеляжу при дії надлишкового тиску гермокабіни. За овальної форми 
поперечного перерізу ускладнюється процес виробництва фрюзеляжу і зростає його вартість [5, 6].

Для успішного забезпечення рятувальних заходів при виникненні позаштатних ситуацій на фюзеляжі виконують додаткові вирізи під спеціальні люки і двері.

За міжнародними нормами [3, 4] потрібно забезпечити, щоб аварійна евакуація всіх пасажирів і екіпажу на землі забезпечувалася протягом 1,5 - 2 хвилин при випущеному або прибраному шасі. Для реалізації цих вимог визначають місце розташування і число необхідних вирізів під стандартні люки і двері. Люк I типу розміром 610×1220 мм розташовують на рівні підлоги кабіни поза зоною крила. Люк II типу розміром 510x1120 мм - поза зоною і в зоні крила, при цьому нижня кромка має бути не вище 250 мм від рівня підлоги і 430 мм від рівня крила. Люк III типу розміром 510x915 мм розташовують у зоні крила на висоті не вище 510 мм від підлоги і не вище 690 мм від крила. Люк IV типу розміром 480x660 мм - у зоні крила не вище 740 мм від підлоги і не вище 910 мм від крила.

Необхідна кількість таких люків визначається числом пасажирів у кожному салоні. При числі пасажирів $10-40$ чоловік обов'язковим $є$ хоча б один люк I типу, при 100 - 200 чоловік - два таких люки, при 200 - 280 чоловік - три, при 280 - 300 чоловік - чотири люки I типу.

Вхідні двері (обов'язково без порогів) вважають люками I типу.

При верхньому розташуванні крила мають бути передбачені люки III типу нагорі фюзеляжу з розрахунку - один люк на 35 пасажирів. Поблизу люків I і II типів (поза зоною крила) мають бути встановлені гумові трапи, що надуваються автоматично.

Вхідні двері, як правило, розміщують по лівому борту фююеляжу. На літаках великої пасажировмісності (більше 250 осіб) двері можуть розташовуватися по обох бортах (пороги не допускаються). Вікна влаштовують між шпангоутами з кроком не менше 500 мм, ширина вікон - $200-230$ мм, висота - 320 - 350 мм. Крок вікон зазвичай узгоджують із кроком крісел, який визначається класом комфортності салонів.

Як зазначено вище, основні параметри і характеристики фрюзеляжу визначають спільно з параметричними розрахунками інших частин літака виходячи з вимог, заданих у технічному завданні, рішення задач вибору геометричних характеристик на етапі ескізного проектування літака при забезпеченні мінімуму маси, а також параметричного аналізу з урахуванням всіх вимог, що ставлять до конструкції [8]. У результаті такої роботи створюють математичну модель фрюзеляжу та інших агрегатів літака, а також математичну модель вигляду всього літака.

Вибір форми носової і хвостової частин визначається мінімальним опором, умовами завантаження-вивантаження вмісту фююзеляжу. Форми цих частин вибирають на базі аеродинамічних досліджень, впровадження нових концептуальних рішень, отриманих у результаті дослідних напрацювань, теоретичних досліджень, наступності конструкції. На рис. 3 зображено загальний вигляд і компонування фюзеляжу регіонального пасажирського літака.

Наступним етапом проектувальних робіт $є$ розроблення конструктивносилової схеми. Конструктивно-силова схема (КСС) фрюзеляжу визначає ступінь участі у сприйнятті навантажень силових елементів. 

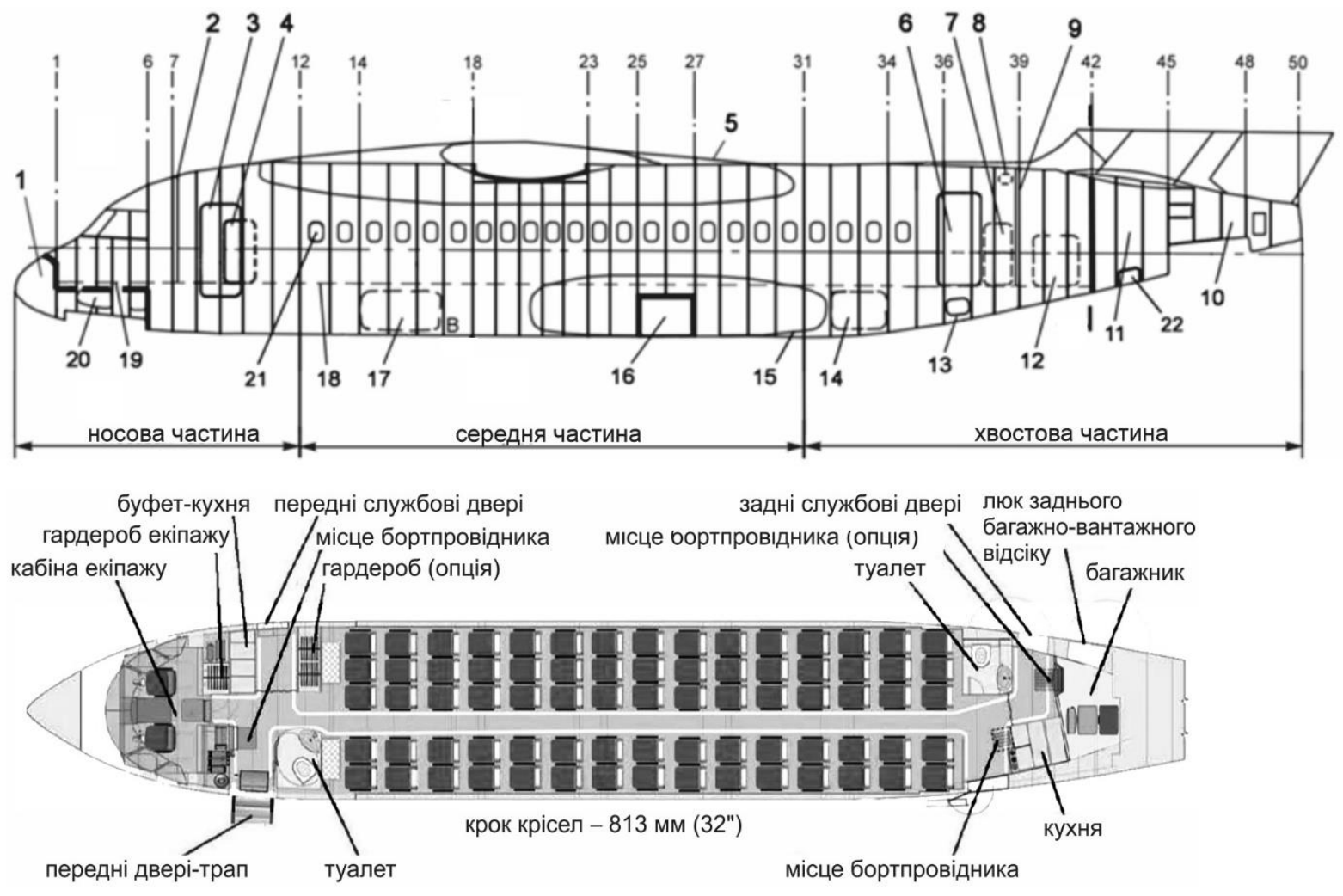

1 - носовий обтічник, 2 - перегородка кабіни екиіпажу, 3 -передні вхідні двері,

4 - передні службові двері, 5 - заліз крила, 6 - задні вхідні двері, 7 - задні

службові двері, 8 - вікно огляду стабілізатора, 9 - перегородка заднього

багажно- грузового відсіку, 10 - відсік ВСУ, 11 - відсік кріплення оперення,

12 - багажні двері, 13 - панель водопостачання, 14 -задній багажний люк,

15 - обтічник шасі, 16 - ніша основних опор шасі, 17 - передній багажний люк,

18 - підлога транспортної кабіни, 19 - підлога кабіни екіпажу,

20 - ніша передньої опори, 21 - бортовое вікно,

22 - люк відсіку оперення

Рисунок 3 - Загальний вигляд і компонування фюзеляжу

регіонального пасажирського літака фрюзеляжу:

У процесі проектування виділяють такі конструктивно-силові елементи

1. Поздовжній набір (стрингери, лонжерони, поздовжні балки).

2. Поперечний набір (шпангоути).

3. Окантування вирізів в обшивці.

4. 3'єднання силових агрегатів.

5. Місцеві посилення.

6. Елементи конструкції.

7. Елементи кріплення.

8. Стики елементів конструкції [7].

На етапі розроблення КСС виконують вибір параметрів елементів конструкції фрюзеляжу - геометричних характеристик, характеристик матеріалів, з яких буде виконуватися той чи інший елемент, їх конструктивні особливості.

Шпангоути поділяють на нормальні та посилені. Нормальні шпангоути служать для утворення форми поперечних перерізів і $€$ опорами стрингерів і 
обшивки. Посилені шпангоути забезпечують передачу зосереджених сил на конструкцію фрюзеляжу. Нормальні шпангоути - це кільцева (або іншої конфрігурації) штампована рама 3 листового матеріалу Z-подібного або швелерного перерізу з просічками під стрингери. У конструкцію кожного шпангоута входить горизонтальна поперечна балка. Нормальні шпангоути спільно з обшивкою навантажуються надлишковим тиском від гермокабіни. Крім того, нормальні шпангоути забезпечують запобігання загальній втраті стійкості конструкції фюзеляжу при значних перевантаженнях у польоті і при посадці [8].

Поперечні балки, що відносяться до силових елементів шпангоута, служать поперечним каркасом підлоги гермокабіни літака.

Посилені шпангоути виконують у вигляді потужних кільцевих рам, утворених внутрішнім і зовнішнім ободами і стінкою. Посилені шпангоути в перерізі виконують у вигляді Z-подібного, швелерного або таврового типу.

Характерною особливістю фрюзеляжу $\epsilon$ те, що він схильний до дії надлишкового тиску в герметичних кабінах. Гермокабіни являють собою циліндричну оболонку, закриту з торців днищами, які $€$ важливим елементом у силовому, ваговому та об'ємному відношенні.

Плоске днище нераціонально з точки зору маси конструкції, але іноді через дефіцит обсягу його доводиться ставити. Найчастіше таке днище виконують із тонкого листа (2...3 мм), підкріпленого силовим набором у вигляді вертикальних і горизонтальних стояків.

Еліптичне днище (непідкріплене) являє собою тонкостінну оболонку, має подвійну кривизну і потребує менше місця для розміщення, ніж сферичне.

Найбільш раціональна форма днища - сферична.

Можуть застосовуватися і днища інших форм. Вибір форми днища часто диктується компонувальними міркуваннями, тому в конструкціях фрюзеляжів можна зустріти всі перераховані види. На транспортних літаках частіше використовують комбінацію сферичних днищ з різною кривизною. Наприклад, смужка сфрери меншої кривизни примикає до циліндричної частини, а до неї купол сфери більшої кривизни. Причому, як правило, застосовують як кільцеве, так і радіальне підкріплення.

Стрингери фюзеляжу найчастіше мають тавровий, Z-подібний або уголковий переріз. Вони прості у виготовленні, але більш схильні до деякого закручування при дії осьових навантажень, що може створювати в обшивці додаткові (невеликі) згибальні деформації між шпангоутами. Тому застосовують і більш складні симетричні форми поперечних перерізів, прагнучи того, щоб головна вісь інерції перерізу профрілю стрингера проходила через вісь заклепочних швів з обшивкою.

\section{Методи розрахунку масово-інерційних та аеродинамічних характеристик фюзеляжу}

На стадії попереднього проектування для аналізу аеродинамічних і масових характеристик літака застосовують методи і залежності, які відображають конструктивні особливості агрегатів в узагальненій формі і мають переважно статистичний характер, що істотно обмежує можливість обґрунтованого вибору параметрів НЧФ.

Для визначення маси фюзеляжу в ході попереднього проектування застосовують залежності, отримані статистичним методом відомі як формули першого наближення $[6,7,11]$. У фрормулах О. А. Бадягіна та В. М. Шейніна 
враховані діаметр, довжина фрюзеляжу, розташування вузлів навішування шасі і двигунів, однак вплив параметрів НЧФ на масу фрюзеляжу не враховано. Формула Козловського враховує площа поверхні фрюзеляжу і таким чином дозволяє опосередковано врахувати геометричні параметри носової частини.

На стадії ескізного проектування злітну масу літака визначають у другому і третьому наближеннях [5, 6, 8], для яких характерне застосування залежностей, які враховують особливості тактико-технічних вимог (ТTT), технології виготовлення і роботи конструкції літака в очікуваних умовах експлуатації.

Застосовувані методи розрахунку маси фюзеляжу в другому наближенні пов'язані з проектувальними розрахунками на міцність основних елементів його конструкції, при цьому внутрішні силові чинники в них визначають на основі балковоі розрахункової схеми. Такий підхід не дозволяє безпосередньо враховувати навантаження від внутрішнього тиску кабіни, обмежуючи його урахування подальшою перевіркою товщини обшивки циліндричної частини фюзеляжу і введенням додаткової складової в загальну формулу маси фрюзеляжу. Геометричні параметри НЧФ враховують у процесі визначення коефріцієнтів форми шляхом графічного інтегрування функції розподілу маси по довжині фрюзеляжу.

На кінцевих стадіях ескізного проектування літака можливе застосування також більш складних моделей і методів, що дозволяють провести детальний аналіз і оптимізацію мас і геометричних параметрів елементів конструкцій. Однак у відкритій літературі $€$ вкрай мала кількість публікацій щодо таких методів.

У ході ітераційного процесу проектування створюють теоретичне креслення з розташуванням елементів конструкції, їх геометричною ув'язкою відносно один одного.

Наступним етапом проектування $є$ розрахунок навантажень, що діють на фрюзеляж для різних розрахункових випадків. Проводиться побудова епюр навантажень, що діють на фрюзеляж, визначають екстремуми навантажень, розглядають можливі варіанти розвантаження фрюзеляжу. На рис. 4 показано вигляд епюр внутрішніх силових чинників, що діють у фрюзеляжі літака транспортної категорії.

Допустимий термін служби пасажирських і транспортних літаків залежить від міцності герметичних кабін. Тому до герметичних кабін мають ставитися підвищені вимоги порівняно 3 іншими агрегатами літака; необхідно забезпечувати хорошу герметизацію кабін, достатню жорсткість і міцність конструкції, необхідний ресурс [1,7]. Складність навантажень, наявність великих вирізів створюють значні труднощі при розрахунках на міцність таких конструкцій. Визначають допустимі розрахункові напруження з урахуванням забезпечення заданого ресурсу. Рівень експлуатаційних навантажень має забезпечувати заданий ресурс конструкції фрюзеляжу. Розробляють розрахункові моделі фрюзеляжу на основі створеної КСС. Створені розрахункові моделі являють собою конструкцію як систему взаємозв'язаних елементів, що враховує взаємодію їх під дією заданих навантажень.

Як розрахункові моделі конструктивно-силових схем елементів і агрегатів конструкції фюзеляжу при проектувальних розрахунках застосовують балкові моделі, аналітичні моделі будівельної механіки, теорії пружності, теорії пластичності, скінченноелементні моделі (СкЕМ) [7, 8]. 
Маса конструкції фрюзеляжу орієнтовно розподіляється між його конструктивними і силовими елементами таким чином: на шпангоути доводиться до $21 \ldots 28 \%$, на поздовжній набір - до $30 \ldots 33 \%$, на обшивку - до $37 \ldots 40 \%[6,7]$.
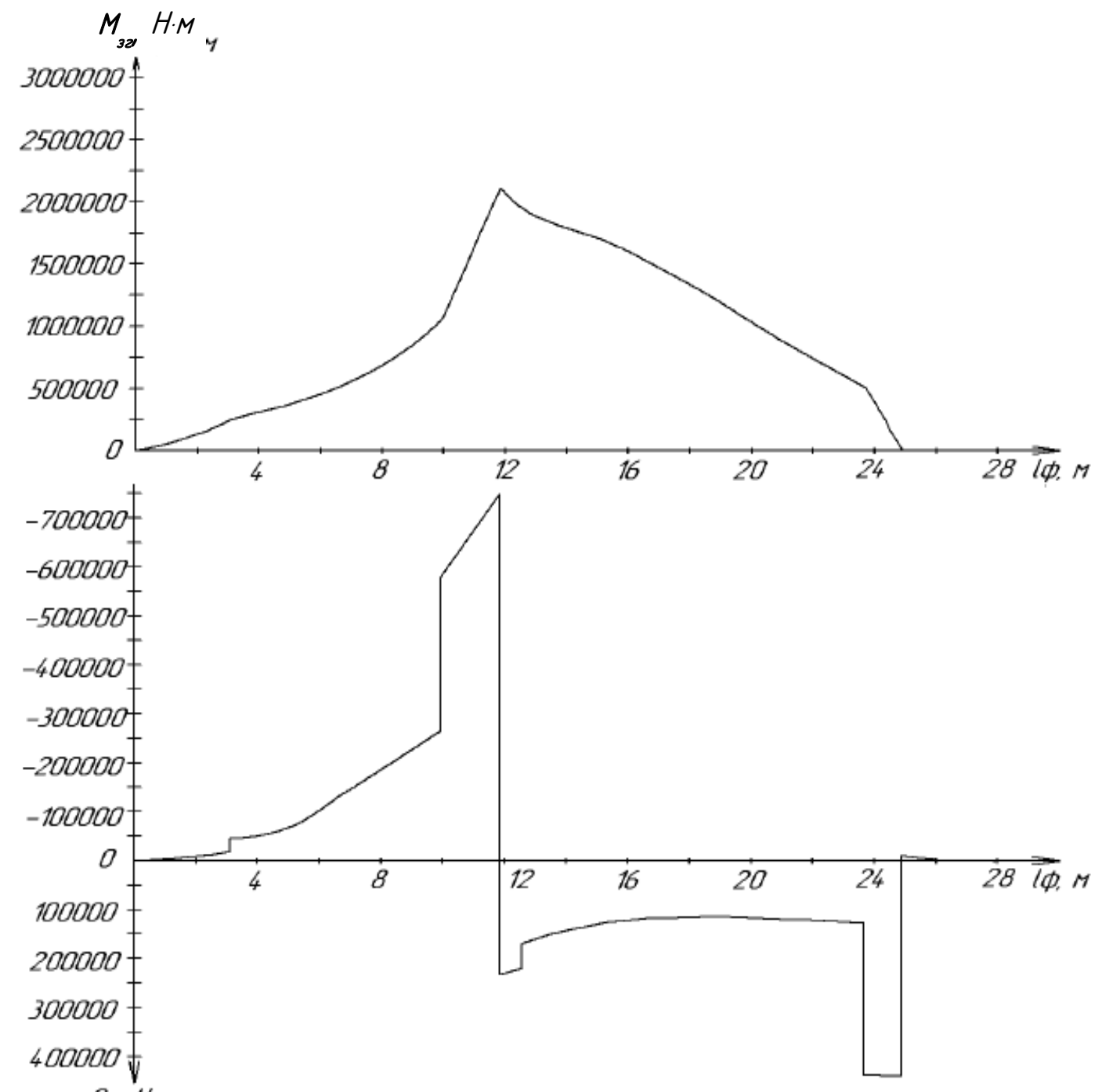

Qy. H

$M K p, H^{+} M$

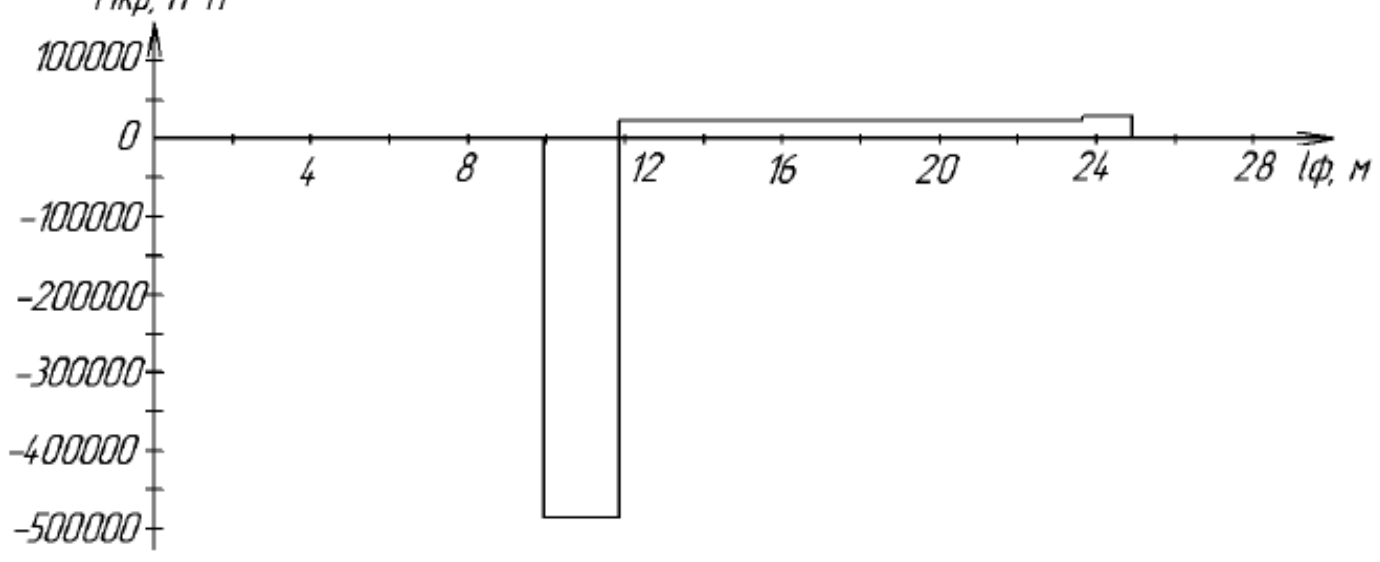

Рисунок 4 - Вигляд епюр внутрішніх силових чинників, що діють у фрюзеляжі літака транспортної категорії 
Розрахунок аеродинамічних характеристик літака в ході попереднього проектування проводять із застосуванням аналітичних методів, що використовують елементи емпіричних і статистичних залежностей. Коефіцієнт лобового опору розглядають як суму коефіцієнтів профільного, індуктивного, хвильового і додаткового опору від місцевих джерел.

При розрахунку профрільного опору враховують подовження НЧФ шляхом розрахунку точки переходу ламінарного примежового шару в турбулентний. Хвильовий опір залежить від подовження і звуження НЧФ, а також від форми твірних (пряма, параболічна чи сферична). При розрахунку додаткового опору за допомогою емпіричних залежностей враховують додатковий опір ліхтаря, приймачів повітряного тиску і щілин кришок люків [10]. Величину індуктивного опору визначають після розрахунку коефіцієнта піднімальної сили фрюзеляжу, на який впливає кут відхилення осі НЧФ від будівельної горизонталі фююзеляжу. Крім того, кут відхилення осі НЧФ впливає на величину пікіруючого моменту фрюзеляжу.

Експериментальні методи визначення аеродинамічних характеристик мають найбільшу точність, проте потребують значних матеріальних і часових витрат, особливо при проведенні льотних експериментів. Застосування даних методів доцільно на пізніх стадіях проектування для підтвердження льотнотехнічних характеристик літака або в процесі розроблення нових розрахункових методів для верифікації результатів.

Чисельні методи розрахунку аеродинамічних характеристик літака значно поширилися в зв'язку з бурхливим розвитком комп'ютерних систем. На відміну від аналітичних методів вирішення системи рівнянь відбувається чисельними методами. При цьому аеродинамічні характеристики отримують на основі значень сил і моментів, що діють на поверхню моделі. Застосування даних методів дозволяє врахувати всі геометричні параметри, задані в тривимірній моделі. Незважаючи на необхідність купівлі програмного забезпечення, підготовки аеродинамічній моделі, проведення розрахунку і аналізу результатів, загальні витрати часу виявляються менше, ніж при натурному експерименті. Це дозволяє застосовувати дані методи на етапі ескізного проектування літака.

\section{Методи тривимірного комп'ютерного моделювання фюзеляжу}

На сучасному етапі розвитку науки і техніки застосування інтегрованих систем комп'ютерного проектування CAD/CAM/CAE/PLM $€$ обов'язковою умовою для розроблення та підтримки життєвого циклу конкурентоспроможної авіаційної техніки. Застосування традиційних креслень загального вигляду, КСС, компонування і теоретичних креслень агрегатів $\epsilon$ можливим разом із тривимірними моделями для забезпечення наочного і однозначного подання інфрормації.

Комп'ютерний проект літака містить такі моделі [1, 2, 9]:

- $\quad$ модель № 1 - майстер-геометрія літака (або модель поверхні літака, що визначає всі точки, що лежать на поверхні літака);

- $\quad$ модель № 2 - модель розподілу простору літака;

- м модель № 3 - моделі стиків і з'єднань по конструктивнотехнологічних роз'ємах;

- $\quad$ модель № 4 - модель геометрії всього виробу (аналітичні еталони всіх деталей, вузлів, агрегатів і літака в цілому), тобто модель повного комп'ютерного визначення літака. 
Для етапів попереднього і ескізного проектування характерно застосування переважно моделей майстер-геометрії і розподілу простору, при цьому модель НЧФ розглядають у складі відповідних моделей фюзеляжу.

У процесі створення майстер-геометрії фюзеляжу проводять визначення, ув'язку і опис геометричних параметрів поверхонь його частин.

Традиційно застосовувані методи нарисної геометрії $[6,12]$ припускають побудову зовнішніх обводів і ув'язку фрорми в два етапи. На першому етапі проводять ув'язку фрорми за допомогою графічних методів (наприклад, спосіб батокси і горизонталей), на другому етапі виконують опис отриманої фрорми аналітичними методами та її фіксацію у вигляді теоретичних ліній і таблиць на теоретичному кресленні агрегата.

Теоретичне креслення $€$ джерелом інформації для побудови математичної моделі агрегата у комп'ютерному середовищі моделювання. Він містить таку інформацію:

1. системи координат агрегату в системі координат літака;

2. розбиття теоретичної поверхні агрегату на сегменти;

3. габаритні та довідкові розміри агрегата;

4. осі конструктивно-силових елементів агрегата;

5. розташування вихідних ліній-носіїв твірних, за якими буде відбуватися формоутворення сегментів поверхні;

6. таблиці з параметрами вихідних перерізів і параметрами лінійносіїв;

7. таблиці з вузловими точками.

Методи тривимірного комп'ютерного моделювання фрюзеляжу за допомогою комп'ютерних систем CAD/CAM/CAE складаються із взаємозв'язаних етапів, застосовуваних раніше. Використання комп'ютерних систем дозволило більш істотно розширити варіантність проектування, ступінь наближення до найкращого результату за більш короткий час [1, 9]. На кожному етапі проектування фрахівці мають можливість повернутися на той рівень, де необхідно виконати зміни, для отримання потрібних характеристик і значень для забезпечення сукупності вимог, що пред'являються до літака.

За допомогою аналітичних методів визначають геометричні параметри літака і його агрегатів, створюють теоретичні креслення літака і його агрегатів. Вони є основою для створення параметричної моделі майстер-геометріі літака.

Поверхні створюються методами аналітичної геометрії, наявними в системах CAD / CAM / CAE.

Маючи теоретичне креслення агрегату, створюють його майстергеометрію.

Поверхні створюють за допомогою методик, основаних на методах аналітичної геометрії, шляхом вирішення рівнянь, що описують поверхні літака. Результатом такого рішення є майстер-геометрія [1, 6].

Майстер-геометрія фрюзеляжу містить майстер-геометрії його частин: носової, середньої і хвостової.

Вихідні дані для створення майстер-геометрії фрюзеляжу: $D_{м \phi}-$ діаметр мідельной частини фюзеляжу; $L_{\phi}$ - довжина фюзеляжу; $\lambda_{H}-$ подовження носової частини фрюзеляжу; $\lambda_{x в}$ - подовження хвостової частини фююзеляжу; форма твірніх носової і хвостової частин фюзеляжу.

На рис. 7 показано параметричну модель майстер-геометрії фрюзеляжу цивільного літака, створену за допомогою комп'ютерної інтегрованої системи 
CAD/CAM/CAE Siemens NX. Майстер-геометрію фюзеляжу ув'язують з майстергеометрією інших агрегатів літака.

\section{Параметричне моделювання майстер-геометрії фюзеляжу}

Моделювання поверхні фюзеляжу відбувається в процесі створення моделі майстер-геометрії літака $[1,6]$ на етапі попереднього проектування. Розглянемо параметричне моделювання майстер-геометрії фрюзеляжу 3 урахуванням особливостей НЧФ. Моделювання доцільно здійснювати параметричними методами на підставі матриці параметрів фююзеляжу (табл. 1), це дозволяє в подальшому автоматизувати внесення змін до моделей та систематизувати дослідження впливу окремих параметрів на масу фююзеляжу.

У табл. 1 наведені дані для шести варіантів фрюзеляжів транспортних літаків різного призначення (рис. 5). Позначення параметрів у таблицях і на кресленнях виконані відповідно до синтаксису редактора виразів системи Siemens NX.

Для створення майстер-геометрії фрюзеляжу використані узагальнене теоретичне креслення (рис. 6) і матриця геометричних параметрів фрюзеляжу. Умовно модель поділяють на моделі носової, центральної і хвостової частин фрюзеляжу.

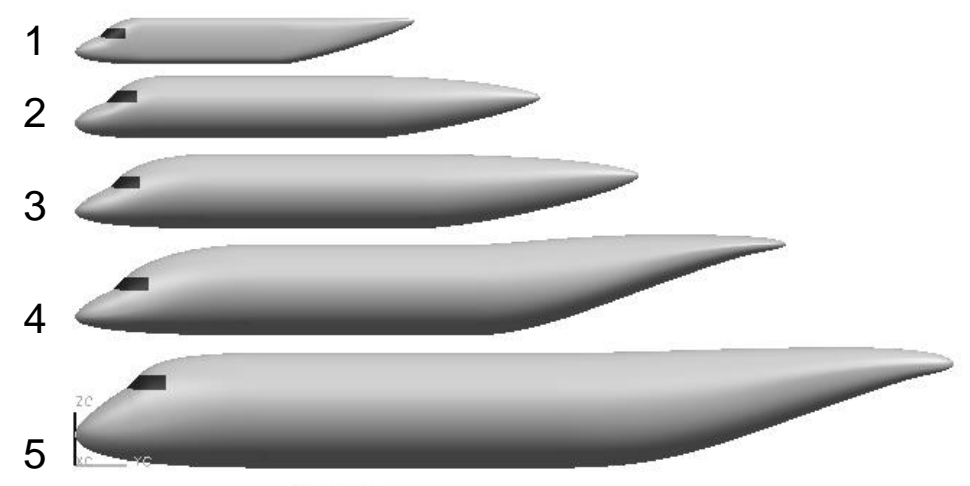

6

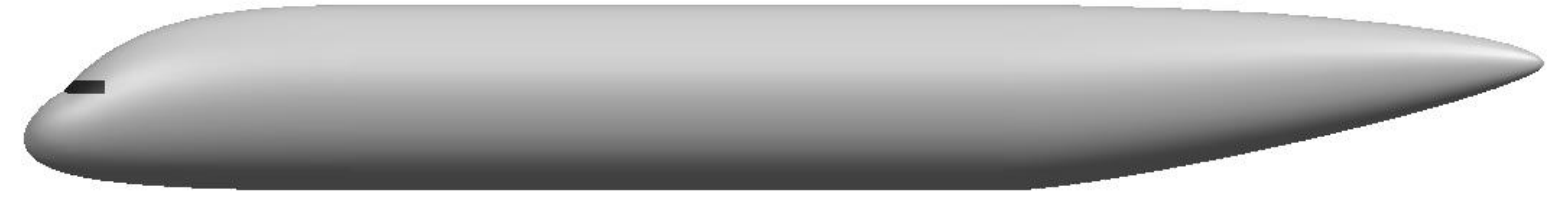

1 - легкий багатоцільовий, 2 - регіональний вантажно-пасажирський, 3 - близькомагістральний пасажирський, 4 - близькомагістральний військовотранспортний, 5 - середньомагістральний військово-транспортний, 6 - далекомагістральний пасажирський

Рисунок 5 - Розглянуті варіанти конфрігурації фююзеляжу літаків

Для побудови параметричної моделі дані матриці геометричних параметрів фюзеляжу необхідно доповнити похідними, довідковими та додатковими параметрами. Ці параметри вибирають переважно 3 міркувань забезпечення гладкості і плавності поверхні фююеляжу, їх значення пов'язані 3 величинами наведеними в матриці параметрів, а їх вплив на ЛТХ не надто значний. 

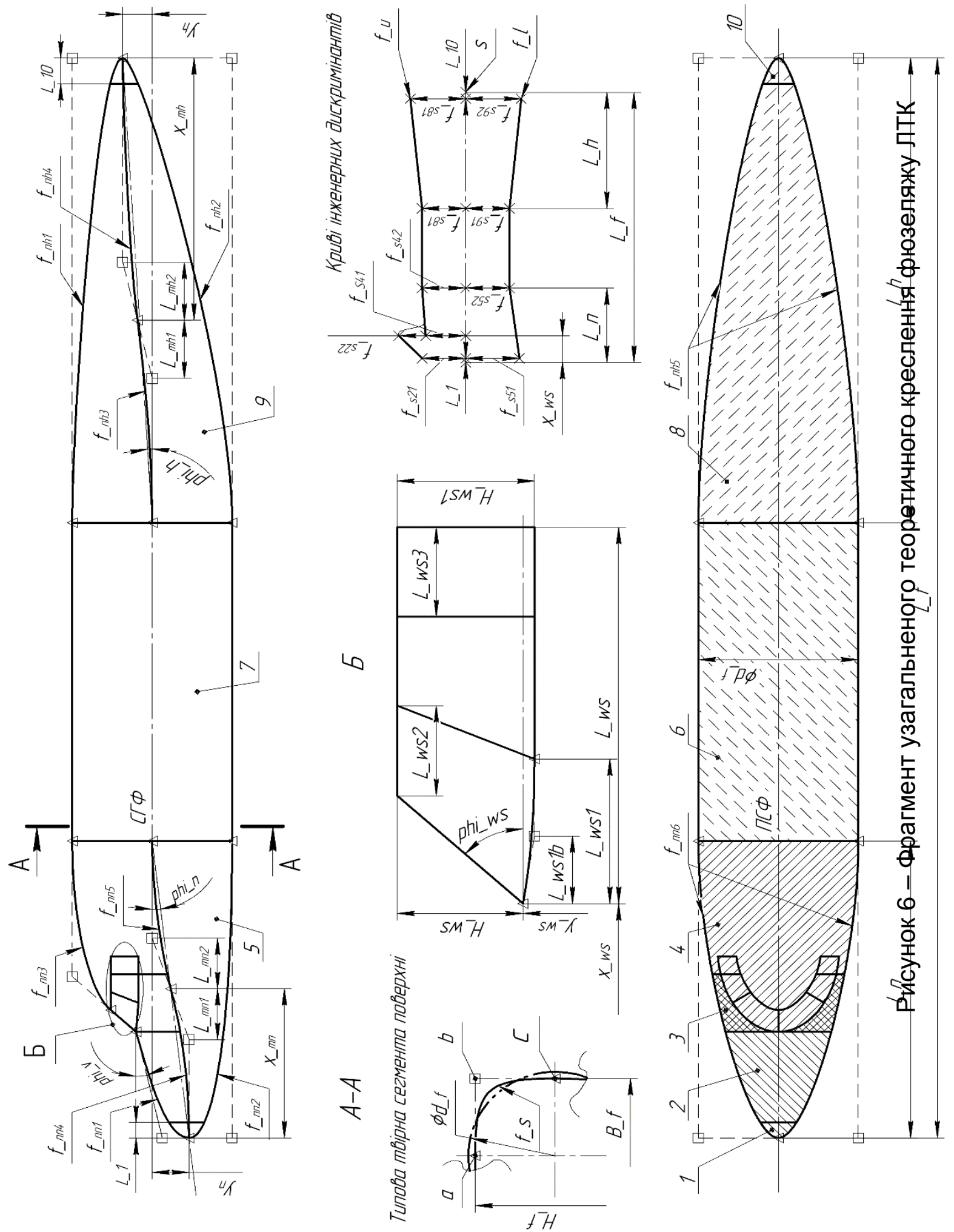

Модель майстер-геометрії фююзеляжу (рис. 7) було додатково розділено на частини за конструктивно-функціональним принципом з метою подальшого асоціативного прикладання навантажень і розрахунку мас частин фрюзеляжу. 
Таблиця 1 - Матриця геометричних параметрів фрюзеляжу

\begin{tabular}{|c|c|c|c|c|c|c|}
\hline Параметр, позначення, одиниця виміру & \multicolumn{6}{|c|}{ Значення } \\
\hline Варіант & 1 & 2 & 3 & 4 & 5 & 6 \\
\hline \multicolumn{7}{|c|}{ Абсолютні } \\
\hline Еквівалентний діаметр фрюзеляжу $\boldsymbol{d} \_f$,мм & 2190 & 2820 & 3350 & 4120 & 5200 & 7723 \\
\hline Кут установки скління phi_ws, град & 40 & 45 & 45 & 45 & 45 & 45 \\
\hline Кут візування phi_v, град & 16 & 17 & 20 & 23 & 30 & 25 \\
\hline Висота скління $\boldsymbol{H} \_\boldsymbol{w s}, \mathrm{Mm}$ & 350 & 480 & 450 & 500 & 550 & 500 \\
\hline Довжина скління $\boldsymbol{L} \_w s$, мм & 1200 & 1400 & 1350 & 1600 & 1800 & 1950 \\
\hline \multicolumn{7}{|c|}{ Відносні } \\
\hline Відносне відхилення НЧФ $\boldsymbol{y} \_\boldsymbol{n}$ & 0,22 & 0,25 & 0,27 & 0,3 & 0,2 & 0,24 \\
\hline Відносне відхилення ХЧФ $\boldsymbol{y} \_\boldsymbol{h}$ & 0,4 & 0,15 & 0,21 & 0,5 & 0,4 & 0,2 \\
\hline Подовження фрюзеляжу lam_f & 7 & 7,65 & 7,8 & 8 & 7,83 & 9,3 \\
\hline Подовження НЧФ lam_n & 1,4 & 1,4 & 1,8 & 2 & 1,65 & 2 \\
\hline Подовження ХЧФ lam_h & 2,8 & 2,8 & 3 & 3,5 & 3,5 & 3,3 \\
\hline $\begin{array}{l}\text { Співвідношення ширини і висоти } \\
\text { перерізу } \boldsymbol{k} \_\boldsymbol{h} \boldsymbol{b}\end{array}$ & 1,12 & 1 & 1 & 1 & 1 & 1,17 \\
\hline Коефіцієнт заповнення перерізу eta_m & 0,93 & $\pi / 4$ & $\pi / 4$ & $\pi / 4$ & $\pi / 4$ & 0,78 \\
\hline
\end{tabular}

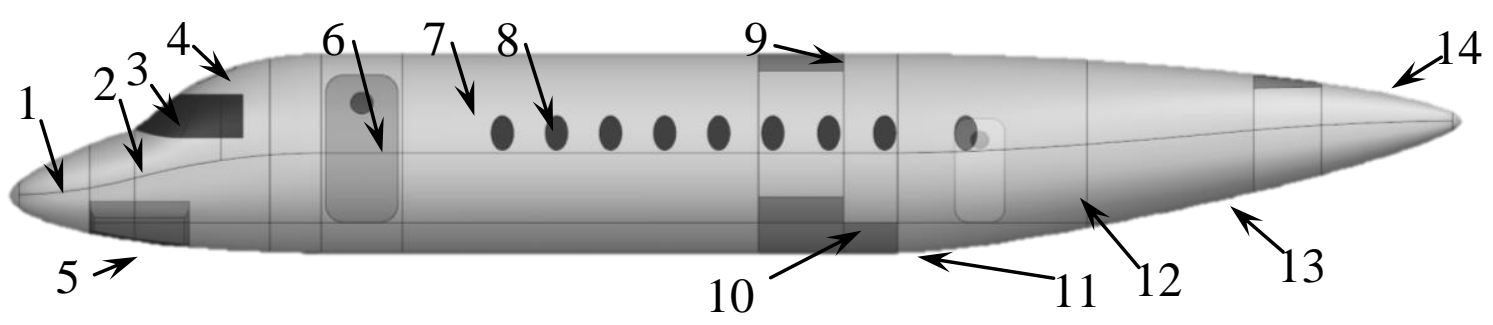

1 - носовий обтічник; 2 - носова частина фюзеляжу; 3 - скління кабіни пілотів;

4 - аварійний люк; 5 - ніша носового стояка шасі; 6 - вхідні двері;

7 - центральна частина фюзеляжу; 8 - ілюмінатори пасажирської кабіни;

9 - стик із центропланом; 10 - ніша основних стояків шасі;

11 - кріплення основних стояків шасі; 12 - аварійний вихід (службові двері);

13 - хвостова частина фрюзеляжу; 14 - кріплення оперення

\section{Рисунок 7 - Модель майстер-геометрії фрюзеляжу літака місцевих повітряних ліній}

\section{Параметрична модель розподілу простору НЧФ}

Реалізація пропонованого методу проектування дозволяє окрім тривимірної комп'ютерної моделі майстер-геометрії розробити модель розподілу простору НЧФ. Для створення моделі розподілу простору літака необхідно вирішити такі задачі: розробити конструктивно-технологічне членування; панелювання; визначити кількість і розташування елементів конструктивно-силового набору фюзеляжу; вирішити питання переліку та розміщення обладнання, устаткування та інші; компонування систем; компонування кабіни екіпажу та пасажирського салону для різної кількості 
пасажирів і комфрортабельності салону. Крім того, виконуються компонування і розрахунки діапазону положення центра мас літака у цілому. На рис. 8 показано фррагмент моделі розподілу простору НЧФ літака транспортної категорії.

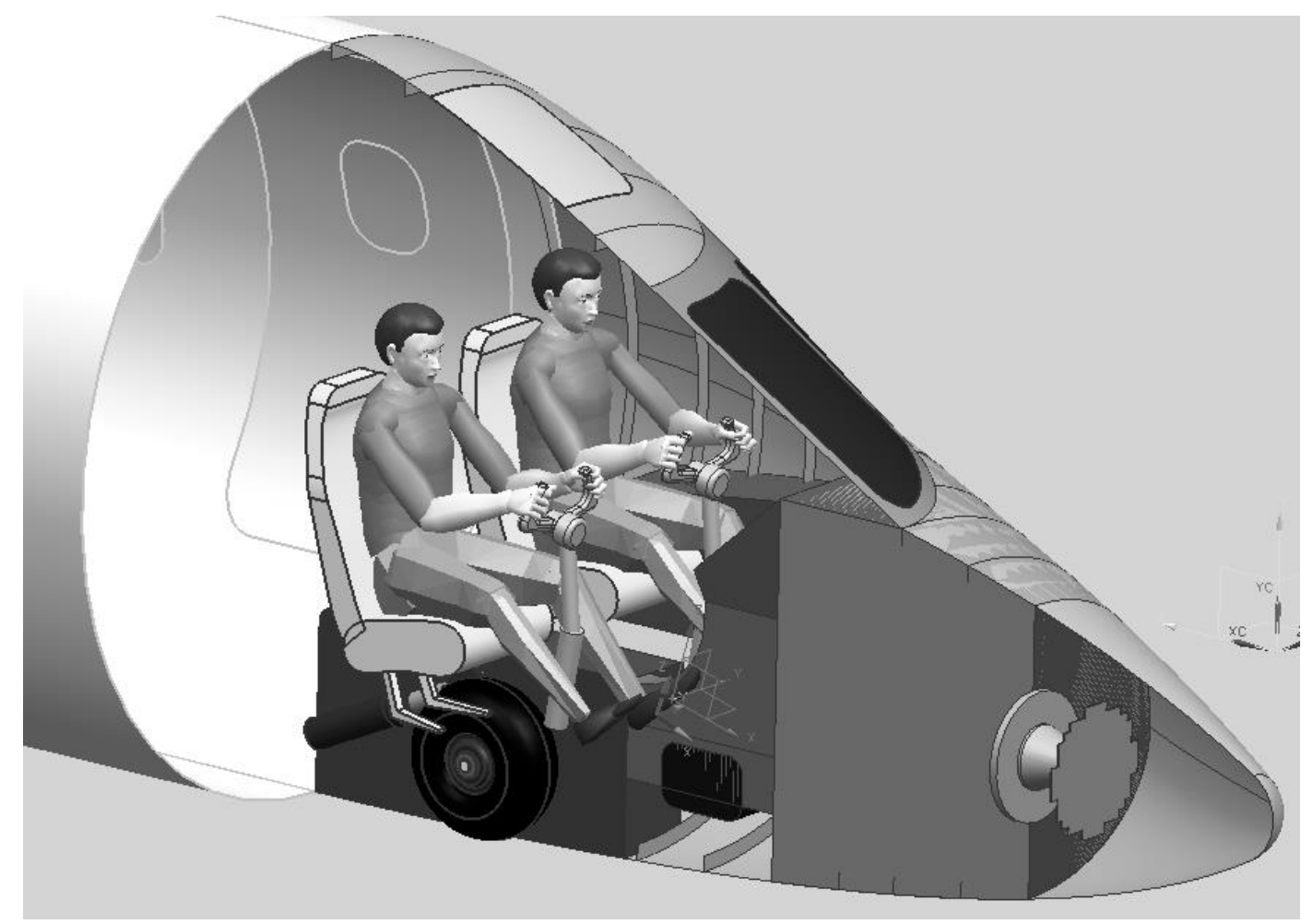

Рисунок 8 - Фрагмент моделі розподілу простору НЧФ літака транспортної категорії

\section{Аналіз компонування і огляду з кабіни пілотів}

Одним із завдань, що вирішують з використанням моделі розподілу простору НЧФ, є визначення кутів огляду з кабіни пілотів з метою оцінювання їх відповідності вимогам безпеки польотів згідно з діючими стандартами ОСТ1 02721-91, АС25.773-1 та вимогами з ергономічності робочих місць екіпажу.

На схемі (рис. 9) показано методику аналізу огляду з кабіни пілотів із використанням параметричної моделі розподілу простору НЧФ [116], що була реалізована за допомогою системи інтегрованого проектування Siemens NX.

Результати аналізу огляду з кабіни пілотів можуть бути подані в формі діаграми кутів огляду (рис. 10, а), яку зручно порівняти з вимогами діючих стандартів чи в фрормі просторової кривої на поверхні фрюзеляжу (рис. 10, б, в), що визначає мінімально необхідні межі скління за умов заданої конфігурації НЧФ і положення пілотів.

Визначення положення пілота, що забезпечує заданий огляд при заданих параметрах скління, проводили ітераційно. Вимоги компонування розглянуті як конструктивні обмеженя щодо розташування пілота. 
Для всіх розглянутих конфігурацій скління істотну складність становило забезпечення огляду з урахуванням кута тангажа при польоті по глісаді, а також розміщення приладової дошки необхідної ширини.

У результаті проведеного аналізу було визначено положення пілота (точки візування), при якому забезпечують потрібні кути огляду (до $125^{\circ}$ вліво, $30^{\circ}$ вверх, $25^{\circ}$ вниз), за розмірів скління та куту лобового скла, що забезпечать прийнятні масові і аеродинамічні характеристики фююзеляжу.

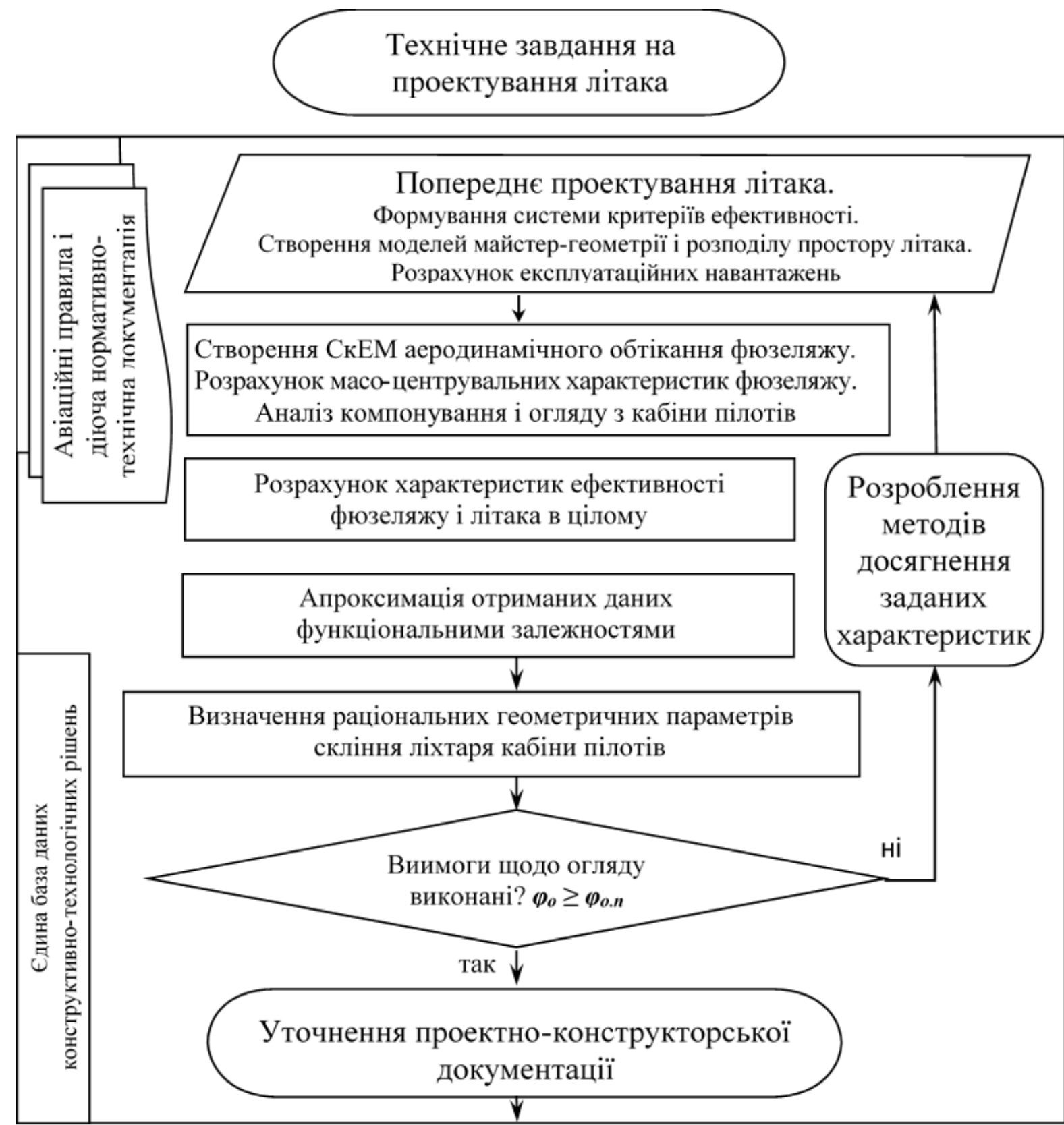

Рисунок 9 - Методика аналізу компонування робочих місць екіпажу й огляду з кабіни пілотів

Дотримана відстань від манекена до теоритичної поверхні становить не меньш 300 мм. 


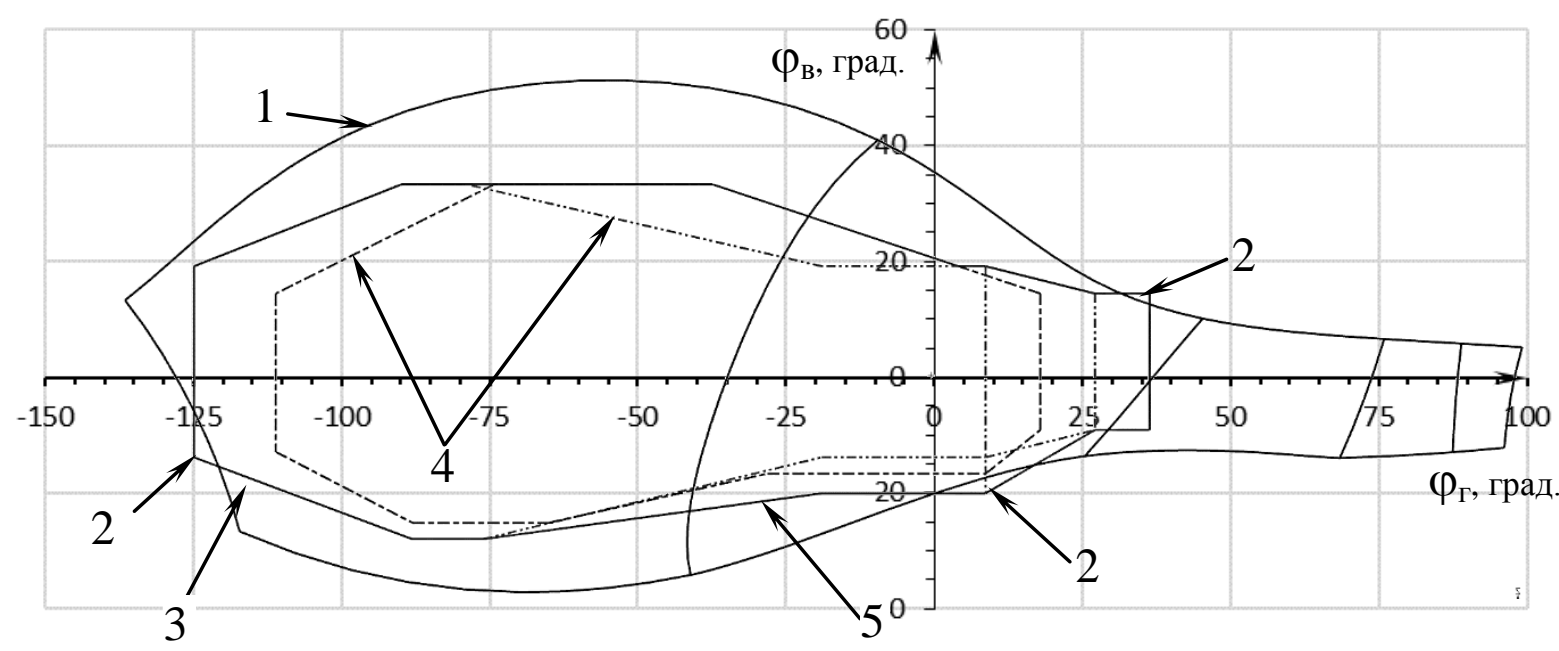

a

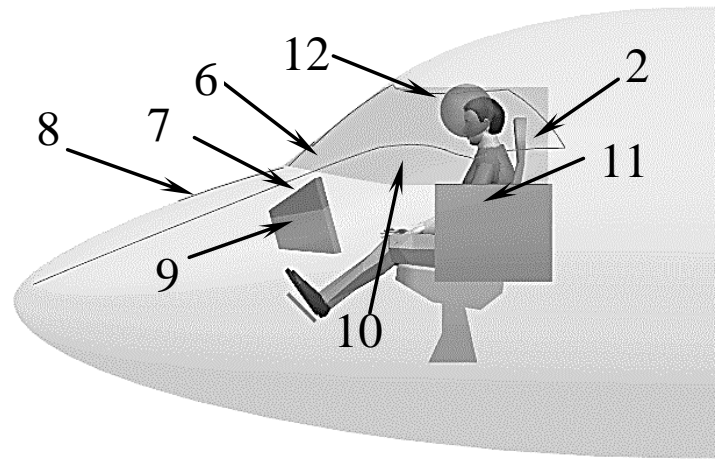

6

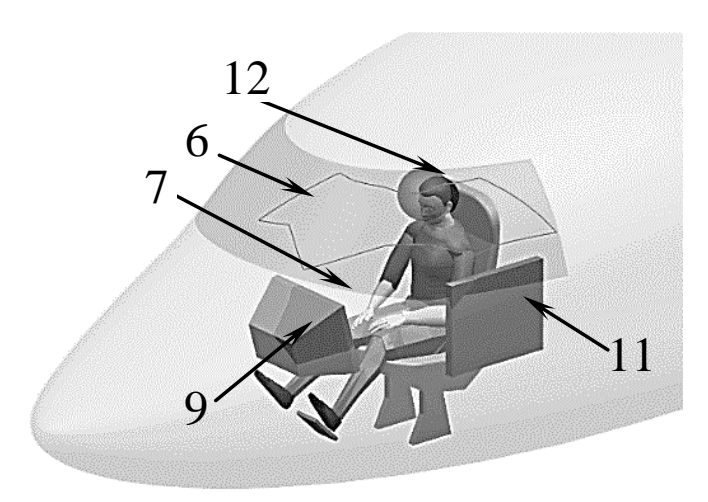

B

а - діаграма кутів огляду; б - необхідні межі скління за вихідних геометричних параметрів; в - необхідні межі скління за рекомендованих геометричних параметрів; 1 - фрактична межа огляду з урахуванням стояків рами скління; 2 - зони недостатнього огляду; 3 - межа мінімального огляду згідно з ОСТ1 02721-91; 4 - межа мінімального огляду згідно з AC25.773-1;

5 - обвідна меж мінімального огляду з урахуванням кута тангажа при польоті по глісаді, 6 - проекція обвідної меж мінімального огляду на поверхню НЧФ;

7 - недостатній обсяг кабіни для розміщення приладової дошки;

8 - недостатній огляд внаслідок затінення обтічником метеорадара;

9 - зона розміщення приладової дошки, 10 - надлишкова площа скління;

11 - зона розміщення підлокітника; 12 - необхідний вільний простір у зоні розташування голови пілота

Рисунок 10 - Аналіз компонування робочих місць і огляду з кабіни пілотів

\section{Моделювання аеродинамічного обтікання фюзеляжу}

Методи, що застосовують для розрахунку аеродинамічних характеристик літака на етапі попереднього проектування, дозволяють урахувати деякі параметри НЧФ, як подовження, форма твірних, фрорма перерізу і кут відхилення носової частини від будівельної горизонталі фюзеляжу.

Недоліком наявних методів $€$ те, що форма НЧФ і перерізу фюзеляжу розглядається як якісний параметр, дозволяючи вибрати тільки один із 
декількох можливих варіантів (конічна, параболічна, еліптична, кругла, прямокутна), а кут відхилення НЧФ враховують тільки при розрахунку коефіцієнта піднімальної сили. Такий підхід не дозволяє провести параметричний аналіз у повному обсязі, проте є прийнятним для верифрікації отриманих результатів.

Необхідні дані про аеродинамічні характеристики фюзеляжу 3 урахуванням геометричних параметрів НЧФ можуть бути отримані за допомогою скінченноелементної моделі аеродинамічного обтікання фююзеляжу.

Для визначення впливу параметрів НЧФ на характер аеродинамічного обтікання фюзеляжу розроблено метод створення відповідної скінченноелементної моделі (рис. 12).

Значення і характер розподілу аеродинамічних навантажень на фюзеляж визначені за допомогою модуля CFX системи інженерного аналізу ANSYS. Ha підставі моделі майстер-геометрії фюзеляжу створено уніфіковану СкЕМ аеродинамічного обтікання фюзеляжу і проведено розрахунки для розглянутих режимів польоту. Для забезпечення мінімального впливу кордонів розрахункової області на характер перебігу і скорочення кількості елементів моделі застосовано розрахункову область еліптичного перерізу з вертикальним положенням більшої осі (розміри області 15x20×50 м), а також подрібнення елементів у зоні примежового шару (рис. 11). Параметри аеродинамічного середовища задані відповідно

до

ГОСТ 4401-81 «Міжнародна стандартна атмосфера». Для виведення і візуалізації результатів розрахунку застосовано компонент CFD-Post модуля CFX. На рис. 13 показано характер розподілу швидкості потоку в площині симетрії розрахункової області і характер розподілу тиску по поверхні фююеляжу.

У процесі верифікації моделі проведено порівняння отриманих аеродинамічних характеристик фрюзеляжу 3 довідковими значеннями, розрахованими за відомою методикою [10]. Задовільні результати точності були

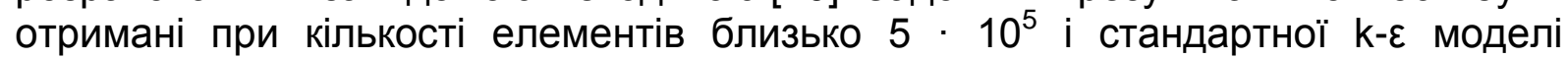
турбулентності.

Подальше уточнення аеродинамічних навантажень доцільно при застосуванні більш точних методів визначення аеродинамічних характеристик.

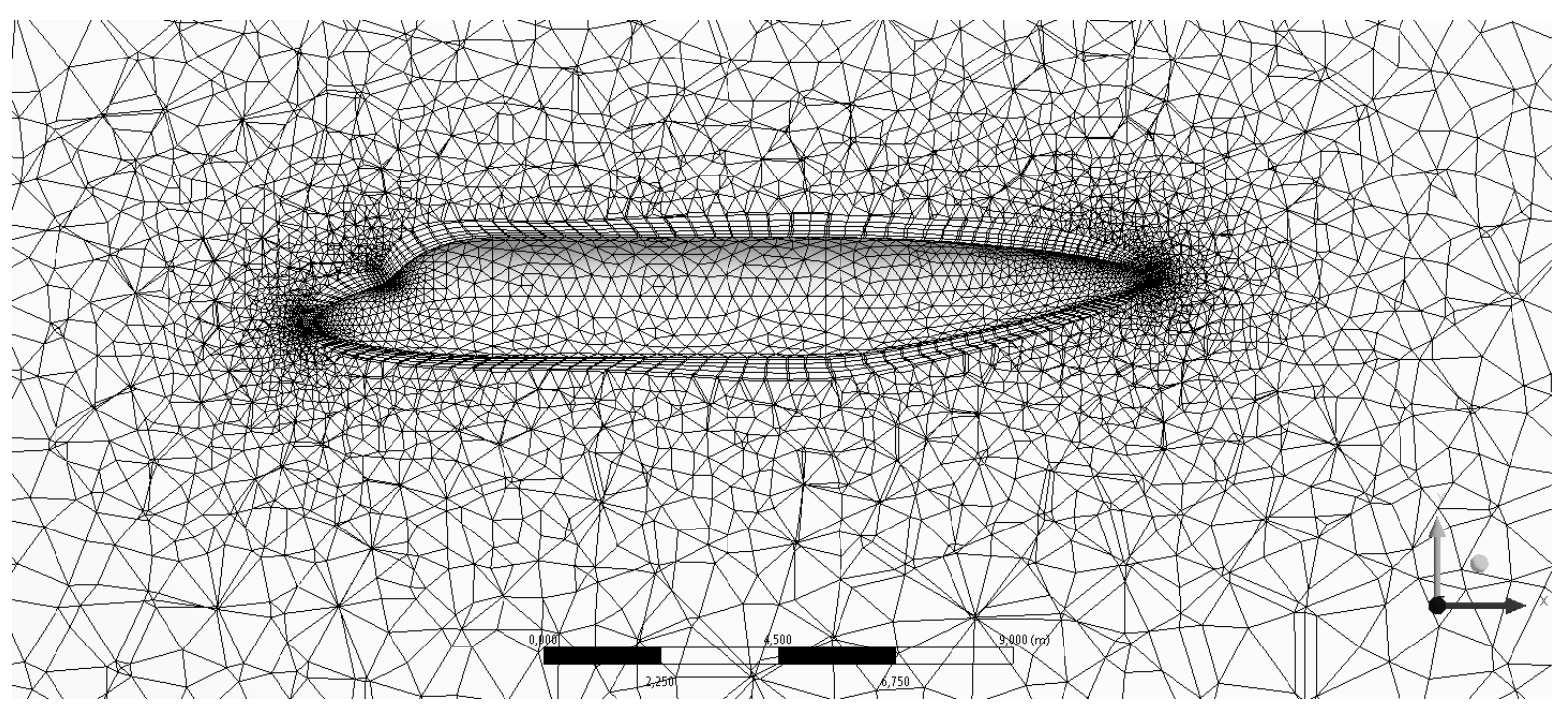

Рисунок 11 - Фрагмент СкЕМ аеродинамічного обтікання фюзеляжу 


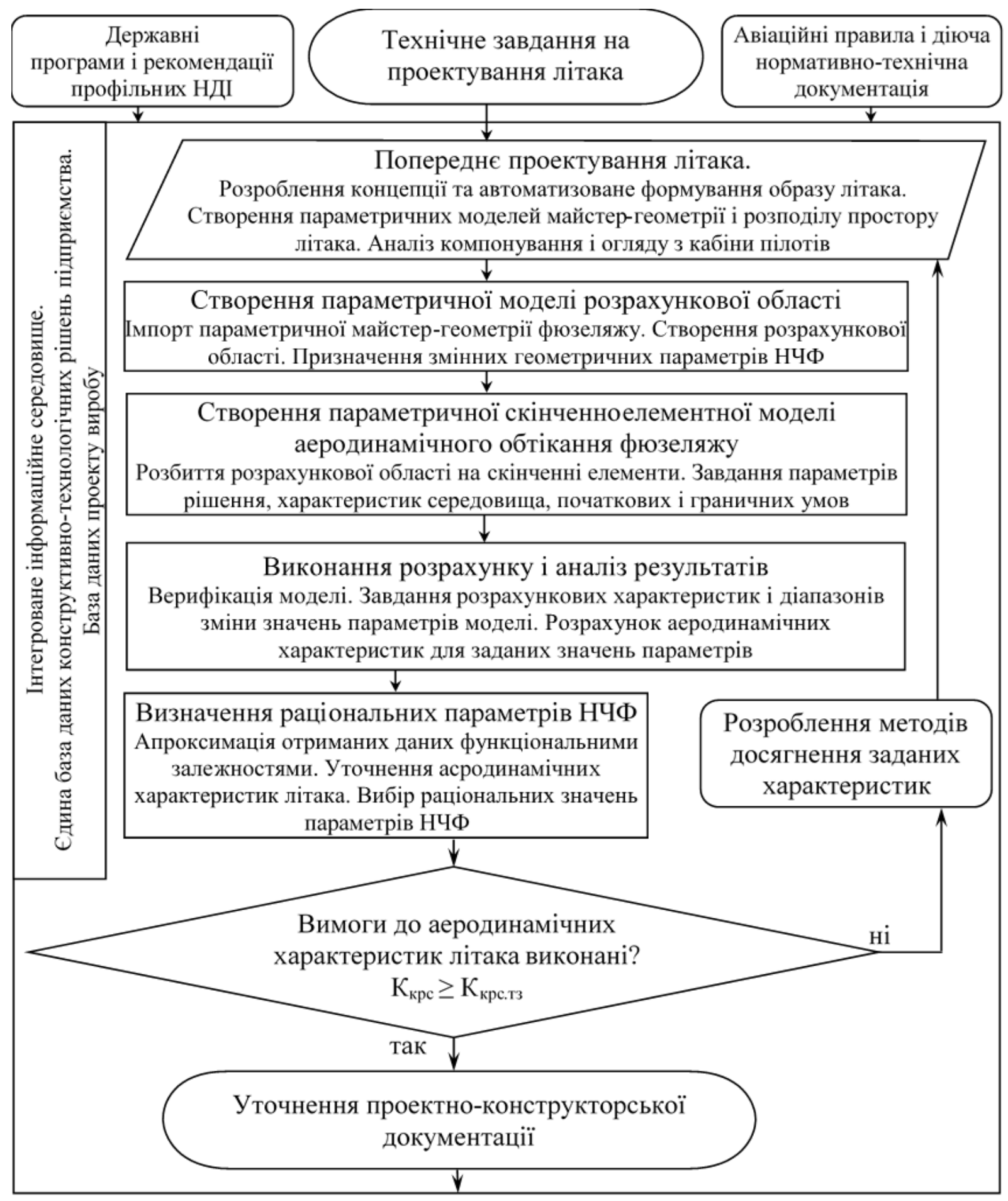

Рисунок 12 - Схема методу моделювання аеродинамічного обтікання фюзеляжу

Для збереження i передачі даних про величину і характер розподілу аеродинамічних навантажень на фрюзеляж значення нормального тиску i дотичних напруження на його поверхні експортовані в текстові фрайли відкритого формату CSV. 


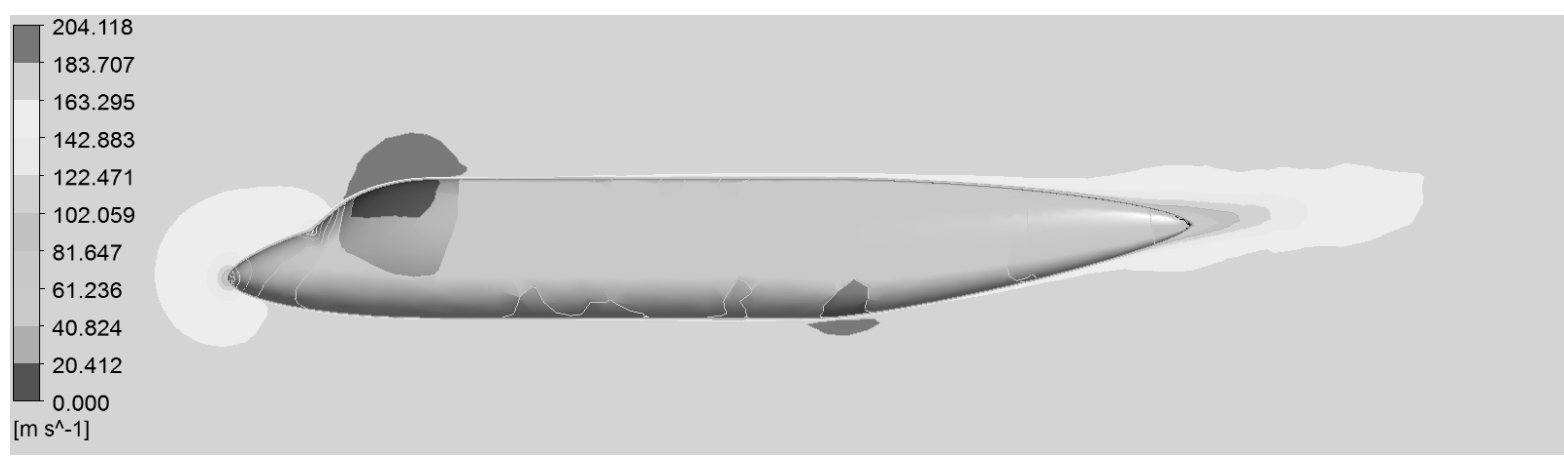

Рисунок 13 - Характер розподілу тиску по поверхні фююеляжу і швидкості потоку в площині симетрії розрахункової області

\section{Аналіз масово-інерційних характеристик конструкції фюзеляжу}

Масово-інерційні характеристики фюзеляжу мають значний вплив на льотно-технічні характеристики літака, таким чином, і на характеристики його ефрективності. Для визначення масово-інерційних характеристик запропоновано метод, схему якого показано на рис. 14.

Для розрахунку маси фрюзеляжу в другому наближенні застосовують методи інженерного аналізу і безпосередньо враховують експлуатаційні навантаження, що діють на фрюзеляж. Для розрахунку цих навантажень необхідно розглянути профріль типового польоту проектованого літака і визначити режими, для яких характерні максимальні значення навантажень, потім побудувати обвідну умов польоту і визначити параметри розрахункових режимів польоту відповідно до АП-25 (пп.25.321 - 25.373).

Розрахункові перевантаження, кути атаки і надлишковий тиск визначені відповідно до вимог CS-25, АП-25, рекомендацій літератури [4, 7, 8], аеродинамічних характеристик літака і параметрів міжнародної стандартної атмосфери (ГОСТ 4401-81). Розрахунковий тиск усередині кабіни не менше еквівалентного висоті 2400 м (0,6 атм).

Таким чином, отримані розрахункові режими польоту дозволяють оцінити максимальні статичні польотні і наземні навантаження на фююеляж при симетричному i несиметричному навантаженні. Врахування динамічних навантажень доцільно виконувати в ході подальшого проектування, на підставі уточнених масо-центрувальних характеристик фюзеляжу і його частин. Вимоги АП-25 щодо птахостійкості враховані як додаткові обмеження за мінімальною товщиною відповідних частин конструкції фюзеляжу.

Для розрахунку масово-інерційних характеристик конструкції фююзеляжу 3 урахуванням форми НЧФ необхідно виконати:

- формування вихідних даних і вимог на підставі Т3 на проектування літака, побудова профілю типового польоту і обвідної умов польоту, визначення параметрів розрахункових режимів польоту;

- створення моделі майстер-геометрії, моделі розподілу простору, виділення функціонально-технологічних частин конструкції фрюзеляжу;

- створення скінченноелементної моделі аеродинамічного обтікання фрюзеляжу i розрахунок розподілу повітряного навантаження по поверхні фрюзеляжу для всіх розрахункових випадків;

- створення узагальненої СкЕМ фюзеляжу, визначення і застосування навантажень, розрахунок напружено-деформованого стану для всіх 
розрахункових режимів, визначення максимальних експлуатаційних i розрахункових напружень, що розтягують і стискають, i еквівалентних напружень $\sigma_{1}, \sigma_{3}, \sigma_{\mathrm{e}}$, за одиничної товщини обшивки;

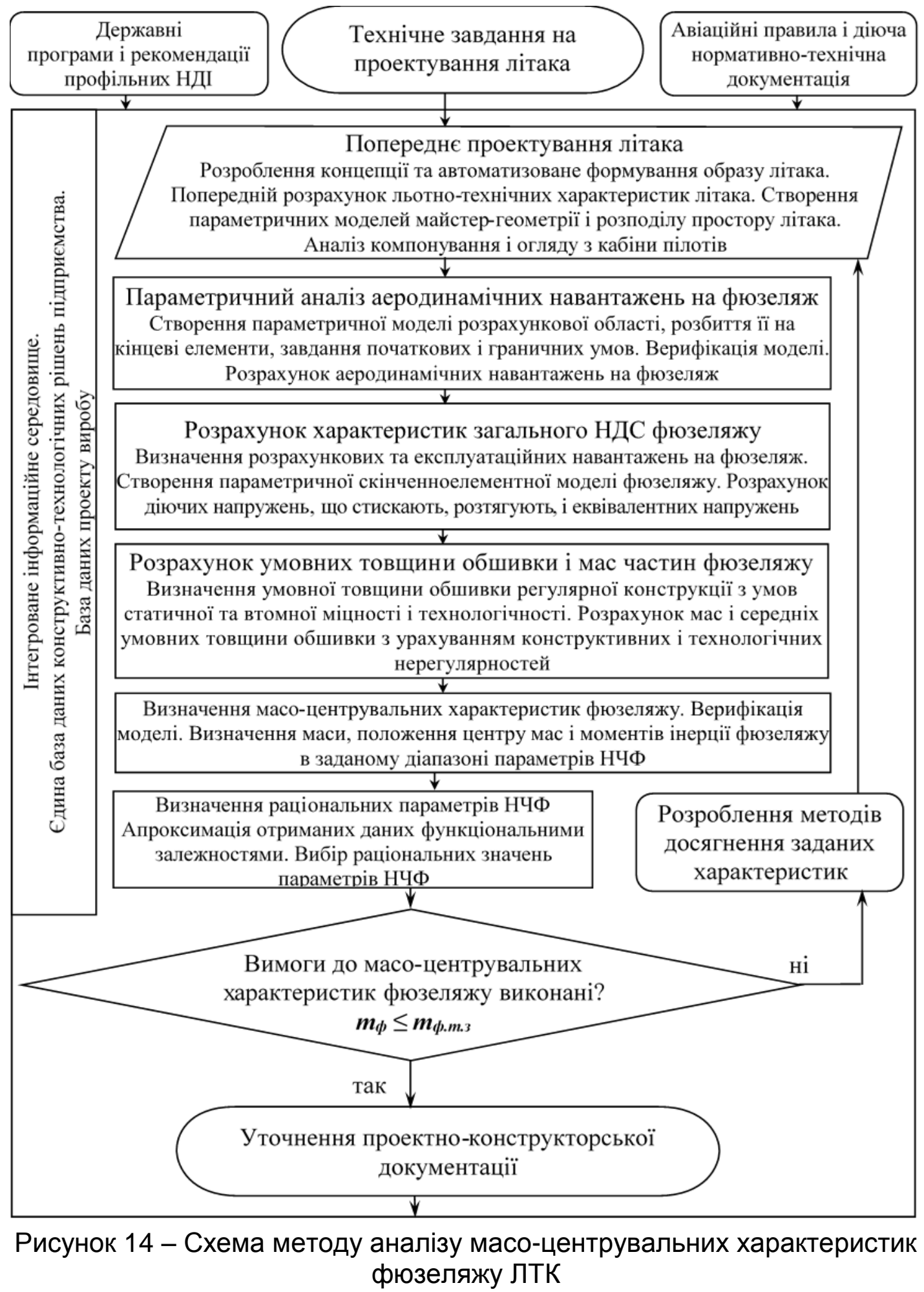

- поелементний розрахунок мінімальної необхідної умовної товщини обшивки регулярної конструкції за максимальними припустимими напруженнями, що розтягують (допустимими), що стискають (граничними), і 
еквівалентними напруженнями. Урахування технологічних обмежень щодо мінімальної товщини обшивки;

- розрахунок мас, умовних товщин і поверхневої питомої ваги обшивок функціонально-технологічних частин конструкції фрюзеляжу з урахуванням конструктивних і технологічних нерегулярностей: обкантовок вирізів, стиків, з'єднань, накладок;

- визначення маси, положення центру мас і моментів інерції фрюзеляжу;

- аналіз результатів розрахунку.

Розрахунок мас агрегатів літака в другому наближенні оснований на результатах інженерного аналізу їх узагальнених моделей за допомогою методів будівельної механіки і розрахунку на міцність [7], що пов'язано 3 необхідністю введення ряду припущень з метою спрощення розрахункової схеми агрегату. Фюзеляж літака транспортної категорії відрізняється від інших агрегатів низкою характерних особливостей, безпосередньо пов'язаних з його функціональним призначенням - розміщенням екіпажу і корисного навантаження, а також інтеграцією агрегатів літака. Фюзеляж сприймає, замикає і врівноважує значні силові потоки маючі велику будівельну висоту і малу площу поперечного перерізу силових елементів, що пов'язано з використанням внутрішнього простору для розміщення корисного навантаження. Крім того, для фрюзеляжу характерна велика кількість додаткових конструктивних елементів і вирізів, складності безпосереднього застосування аналітичних методів у чистому вигляді, що потребує їх доповнення статистичними залежностями.

Застосовувані раніше методи розрахунку маси фрюзеляжу в другому наближенні [13] пов'язані з проектувальними розрахунками на міцність основних елементів його конструкції, при цьому внутрішні силові чинники в них визначають на основі балкової розрахункової схеми. Такий підхід не дозволяє безпосередньо враховувати навантаження від внутрішнього тиску кабіни, обмежуючи його врахування подальшою перевіркою товщини обшивки циліндричної частини фюзеляжу і введенням додаткової складової в загальну формулу маси фююзеляжу.

Пропонований метод орієнтований на більш ранні стадії ескізного проектування для уточнення геометричних параметрів і форм фрюзеляжу і його частин.

У пропонованому методі розрахунку застосовано скінченноелементну модель фюзеляжу , що складається з елементів типу «оболонка»; це дозволяє врахувати сприйняття внутрішнього тиску поверхнею складної фрорми в поєднанні 3 масовими i аеродинамічними навантаженнями. Вихідною геометричною моделлю $є$ майстер-геометрія фрюзеляжу. Асоціативний зв'язок скінченноелементної і параметричної моделі майстер-геометрії дозволяє автоматизувати перестроювання моделі при внесенні змін і виконувати таким чином оцінку впливу геометричних параметрів на масу фюзеляжу і його частин. При цьому збережена спадкоємність із застосовуваними раніше методами щодо вихідних даних, класифрікації мас конструкції фрюзеляжу і обліку додаткових конструктивних і технологічних чинників.

Запропонований метод реалізований за допомогою систем інтегрованого проектування Siemens NX і інженерного аналізу ANSYS і апробований в ході попереднього проектування літака місцевих повітряних ліній і легкого літака цивільної авіації. 
Модель для розрахунку характеристик загального НДС фрюзеляжу створено згідно з наведеною розрахунковою схемою (рис.15).

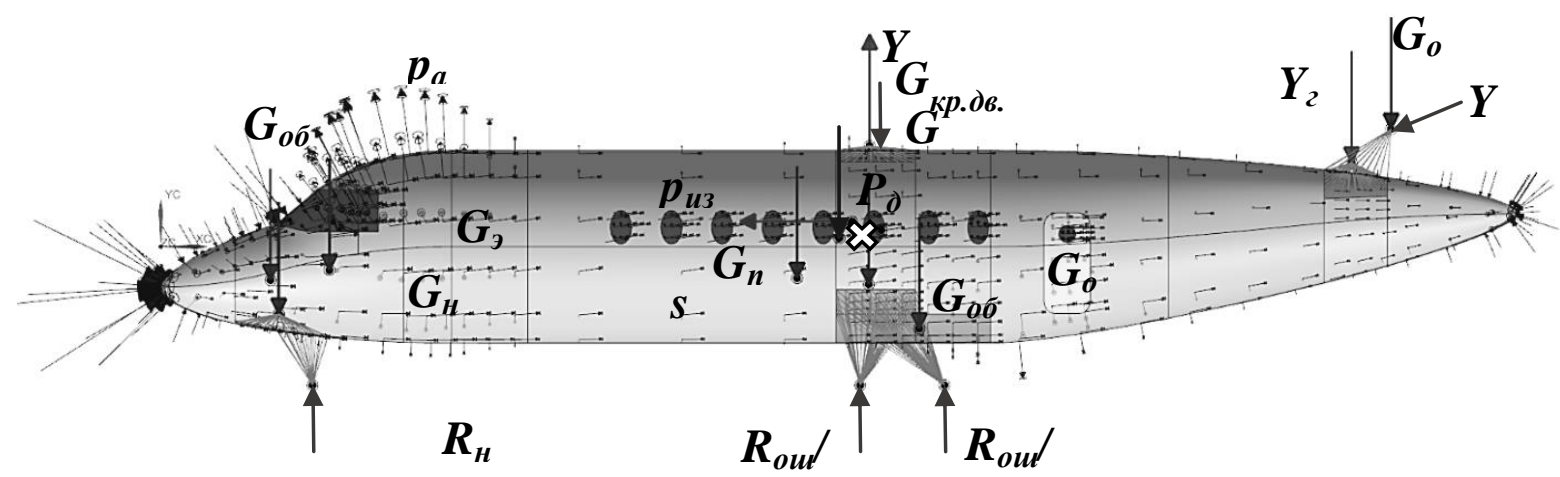

Рисунок 15 - Розрахункова схема фрюзеляжу

При створенні СкЕМ фрюзеляжу (рис. 16) були використані елементи трикутної форми типу оболонка (CTRIA3). НДС узагальненої моделі розраховано при одиничній товщині оболонки.

Для забезпечення розподілу навантажень відповідно до раніше розробленого компонування літака модель майстер-геометрії доповнена ескізом у площині симетрії літака, що містить точки прикладання навантажень. У процесі створення СкЕМ точки прикладання навантажень пов'язані 3 відповідними частинами поверхні моделі майстер-геометрії фююзеляжу елементами типу RBE3, що забезпечують передачу навантажень без зміни жорсткості моделі. Закріплення СкЕМ зроблено в точці, що відповідає центру мас літака, пов'язаного з контуром кріплення центроплана.

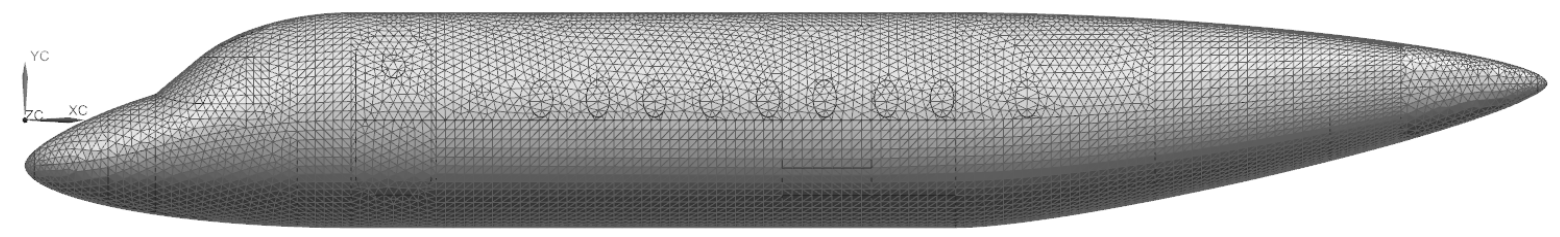

Рисунок 16 - СкЕМ фюзеляжу літака місцевих повітряних ліній

Запропонований метод розрахунку масо-інерційних характеристик оснований на визначенні характеристики загального НДС моделі фююзеляжу при одиничній товщині обшивки ( $\delta=1$ мм), для розглянутих розрахункових режимів (отриманих значеннях експлуатаційних напружень, що розтягують $\sigma_{1}$, стискають $\sigma_{3}$, і еквівалентних напружень $\sigma_{\mathrm{e}}$ ). На рис. 17 показано характер розподілу еквівалентних напружень Мізеса по поверхні фююзеляжу при одиничній товщині обшивки для кожного і-го елемента моделі.

Для визначення максимальних експлуатаційних напружень скористаємося інструментом «Обвідна» (Envelope) панелі результатів, вибравши результати розрахунків як вихідні дані. Даний інструмент дозволяє проводити порівняння напружень у кожному і-му елементі в різних розрахункових випадках і визначити їх максимальне значення. 
Для фрюзеляжу характерне виникнення найбільших напружень, що розтягують у панелях із значною кривизною, викликаною розміщенням скління кабіни пілотів, а також у місцях прикладання навантажень від шасі і крила, проте максимальні значення цих напружень у різних розрахункових випадках відрізняються.

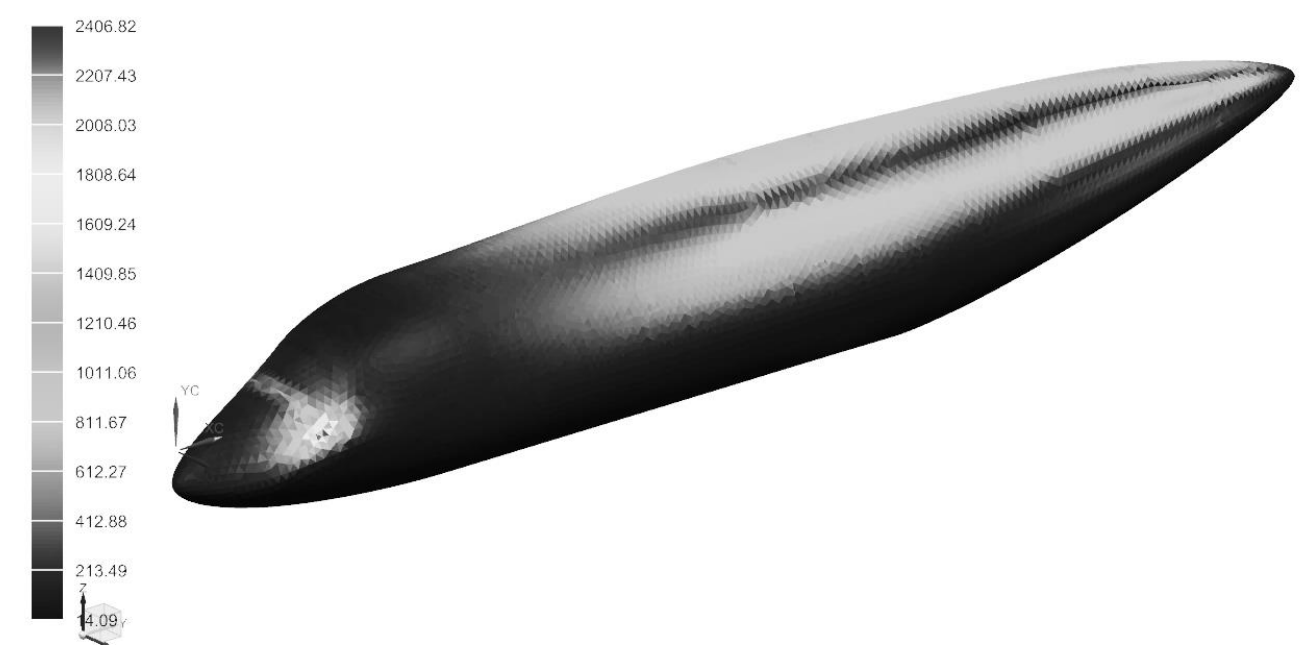

Рисунок 17 - Характер розподілу еквівалентних напружень

Для розрахунку необхідної товщини умовної обшивки визначимо граничні допустимі напруження з умов міцності і довговічності до конструкцій $[1,8]$ :

$$
\sigma_{1_{i}}^{\max } \leq\left[\sigma_{\mathrm{z}}\right] ; \sigma_{3_{i}}^{\max } \leq\left[\sigma_{\mathrm{Kp}}\right] ; \sigma_{e_{i}}^{\max } \leq\left[\sigma_{\mathrm{B}}\right],
$$

де $\left[\sigma_{д}\right]$ - допустимі напруження матеріалу при заданому ресурсі $T=80000$ польотів; $\left[\sigma_{\text {кр }}\right]$ - критичні напруження втрати стійкості; $\left[\sigma_{\text {в }}\right]$ - межа міцності матеріалу; $\sigma_{e_{i}}^{\max }{ }^{\mathrm{p}}=f \cdot \sigma_{e_{i}}^{\max }-$ максимальні розрахункові напруження; коефріцієнт безпеки $f=1,5$. формулою

Необхідну довговічність елементів конструкції $\boldsymbol{N}$ розраховують за

$$
N=T \cdot \eta,
$$

де $T$ - заданий ресурс, $\eta$ - коефіцієнт надійності, що визначається згідно із чинними нормами льотної придатності. На етапі ескізного проекту коефіцієнт надійності $\eta$ приймають таким, що дорівнює 4.

Для більшості літаків транспортної категорії як основний матеріал конструкції фрюзеляжу застосовують алюмінієвий сплав. Довговічність $\boldsymbol{N}$ металевих елементів конструкції описується статистичною залежністю кривої втоми

$$
N \cdot \sigma_{0}^{m}=C,
$$

де $\sigma_{0}$ - напруження віднулювого циклу; $m$ i $C$ - експериментально визначаються як константи, що враховують ресурсні властивості матеріалу і конструктивні нерегулярності. 
Допустимі напруження віднулевого циклу $\left[\sigma_{0}\right] 3$ урахуванням забезпечення заданого ресурсу дорівнюють

$$
\left[\sigma_{0}\right]=\sqrt[m]{C / N^{*}}
$$

При середньому значенні діючих напружень більше нуля справедлива формула Одинга:

$$
\sigma_{0}=\sqrt{2 \sigma_{a} \sigma_{\max }}
$$

де $\sigma_{\mathrm{a}}$ - амплітудні напруження в розглянутому типовому польоті; $\sigma_{\max }$ максимальні діючі напруження.

Тоді, допустимі напруження дорівнюють:

$$
\left[\sigma_{\text {д }}\right]=\left[\sigma_{\max }\right]=\frac{\left[\sigma_{0}\right]^{2}}{2 \sigma_{\mathrm{a}}} .
$$

Критичні напруження втрати стійкості для панелей фюзеляжу 3 урахуванням конструктивно-технологічних міркувань при виборі кроку елементів, що підкріплюють, становлять не менше $\left[\sigma_{\mathrm{kp}}\right] \approx 0,8 \cdot \sigma_{\mathrm{B}}$.

Необхідну товщину умовної обшивки в кожному елементі визначимо виходячи з максимальних діючих експлуатаційних напружень при одиничній товщині обшивки і граничних допустимих напружень.

За незмінної фрорми оболонки для забезпечення міцності товщину умовної обшивки в кожному і-му елементі необхідно збільшити пропорційно відношенню діючих у ньому напружень до максимально допустимих, за умов забезпечення статичної міцності і ресурсу:

$$
\delta_{1_{i}} \geq \frac{\sigma_{1_{i}}^{\max }}{\left[\sigma_{\mathrm{\mu}}\right]} ; \delta_{3_{i}} \geq \frac{\sigma_{3_{i}}^{\max } \cdot f}{\left[\sigma_{\mathrm{Kp}}\right]} ; \delta_{e_{i}} \geq \frac{\sigma_{e_{i}}^{\max } \cdot f}{\left[\sigma_{\mathrm{B}}\right]} .
$$

Значення товщини умовної обшивки в кожному з елементів моделі визначимо за трьома критеріями міцності згідно 3 наведеними вище фрормулами, скориставшись інструментом «редукція» (Reduction) панелі результатів і вибравши максимальні експлуатаційні напруження як вихідні дані.

Крім того, при визначенні необхідної товщини умовної обшивки необхідно враховувати технологічні обмеження за мінімальними товщинами матеріалів.

Скориставшись інструментом «Обвідна» (Envelope), визначимо максимальне значення необхідної товщини умовної обшивки для кожного і-го елемента СкЕМ:

$$
\delta_{i} \geq \max \left\{\delta_{1_{i}}, \delta_{3_{i}}, \delta_{e_{i}}, \delta_{\min }^{\mathrm{T}}\right\} .
$$

На рис. 17 показано характер розподілу необхідної товщини умовної обшивки фюзеляжу літака місцевих повітряних ліній з урахуванням навантажень у всіх розглянутих розрахункових режимах, що забезпечує міцність i технологічність виходячи з розглянутих критеріїв.

Результати розрахунку збігаються з природним характером розподілу матеріалу: найбільші товщини отримані в місцях розташування стикових вузлів і панелей зі значною кривизною. При цьому товщину нижніх і бічних панелей центральної частини фрюзеляжу, а також бічних панелей хвостової частини визначено виходячи з максимальних напружень, що стискають; товщину верхніх панелей центральної і хвостової частини - з максимальних напружень, що 
розтягують. Панелі НЧФ (за винятком панелей під склінням) і нижньої частини ХЧФ навантажені мало, їх товщина отримана з технологічних міркувань.

Отримані значення товщини умовної обшивки відповідають ідеалізованій регулярній оболонці. Насправді фрюзеляж містить безліч конструктивних нерегулярностей [7] (вирізів, роз'ємів, стиків), маса яких на етапі ескізного проектування визначається на основі досвіду проектування або за статистичними залежностями. Наявність таких нерегулярностей і додаткових технологічних чинників врахуємо при розрахунку маси частин конструкції фюзеляжу.

У загальному вигляді маса фююзеляжу складається з маси регулярної конструкції $m_{p \kappa}$ (яка визначається виходячи з проектувального розрахунку

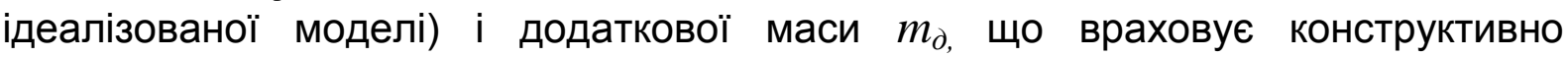
технологічні чинники. Тоді маса окремої частини фюзеляжу $\boldsymbol{m}_{\boldsymbol{i}}$ може наведена у вигляді

$$
m_{i}=m_{p \kappa . i}+m_{\partial . i}
$$

Масу регулярної конструкції кожної з розглянутих частин фрюзеляжу визначимо виходячи з отриманої товщини умовної обшивки

$$
m_{\text {рк.i }}=s_{i} \cdot \delta_{i} \cdot \rho_{i}\left(\sigma_{\text {в.i }} / \sigma_{\text {в.q }}\right) \text {, }
$$

де $s_{i}$ - площа поверхні; $\delta_{i}$ - середня товщина умовної обшивки; $\rho_{i}-$ густина матеріалу; $\sigma_{\text {в.i }}$ - межа міцності матеріалу $[2,24,91]$ даної частини фрюзеляжу; $\sigma_{\text {в.ф }}$ межа міцності матеріалу, прийнятого при розрахунку товщини умовної обшивки.

Для обтічника РЛС, панелей носової частини фюзеляжу, люка аварійного покидання кабіни пілотів необхідно додатково враховувати вимоги забезпечення птахостійкості. Згідно з дослідженнями ЦАГІ товщина обшивки панелей, виконаних з алюмінієвих сплавів, розташованих під кутом більше $30^{\circ}$ до осі фрюзеляжу, має становити не менше 1.6 мм, з умови рівноміцності товщина склопластикового обтічника РЛС тоді становитиме 3 мм. За даними виробників авіаційних стекол товщина лобових стекол кабіни пілотів сучасних літаків транспортної категорії становить 20...25мм, бічних - близько 10мм. При розрахунку маси скління використано середнє значення 15 мм. Товщина скла ілюмінаторів пасажирської кабіни дорівнює 10 мм.

Додаткова маса $[6,7,11] m_{\partial . i}$ містить масу додаткових елементів конструкції $m_{\partial \kappa}$ і додаткову масу, обумовлену конструктивно-технологічними чинниками $m_{\kappa m}$ :

$$
m_{\partial . i}=m_{\partial . \kappa}+m_{\kappa m} .
$$

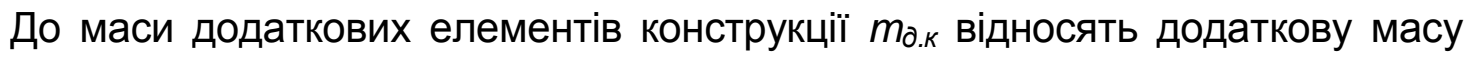

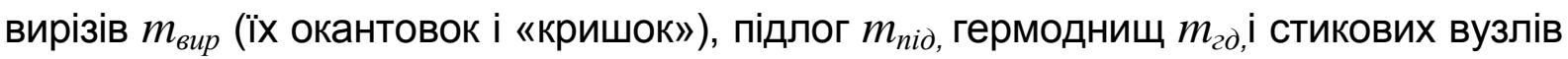
$m_{c m \kappa}$ :

$$
m_{\partial . \kappa}=m_{\text {вup }}+m_{\text {nid }}+m_{\text {гд }}+m_{\text {стк }} \text {. }
$$

Додаткову масу вирізу знаходять як масу регулярної конструкції, помножену на коефіцієнт вирізу:

$$
m_{\text {вир. } i}=k_{i} m_{p k . i} \text {. }
$$

Коефіцієнти вирізів вибрають згідно з рекомендаціями, основаними на проектуванні аналогічних конструкцій.

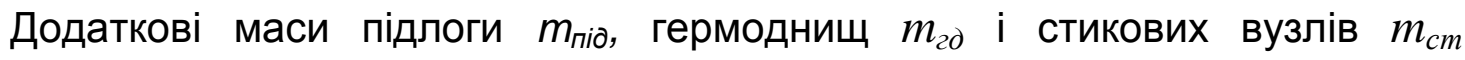
визначені за статистичними залежностями [7]: 


$$
\begin{gathered}
m_{\text {підлоги }}=4,48 \cdot d_{\phi}{ }^{2} \cdot \lambda_{\phi} ; \\
m_{г д}=1,6 \cdot\left(p_{\text {над }}+1\right) \cdot d_{\phi}{ }^{3} ; \\
m_{c m}=0,01275 \cdot m_{0} .
\end{gathered}
$$

Маса підлоги розподілена між носовою, центральною і хвостовою частинами пропорційно площам їх поверхні. Маса гермоднищ розподілена між нішами шасі, носовою і хвостовою частинами. Маса стикових вузлів розподілена між силовим поясом центральної частини фюзеляжу, нішами шасі і хвостовою частиною.

До додаткової маси, обумовленої конструктивно-технологічними чинниками [7] $m_{\kappa m}$, відносять масу з'єднань $m_{3}$, роз'ємів $m_{\text {роз }}$, додаткову масу, пов'язану з неточністю виготовлення деталей $m_{\text {нm }}$ і обмеженою номенклатурою напівфабрикатів $m_{\text {ном. }}$.

$$
m_{\kappa m}=m_{\text {раз }}+m_{3 д}+m_{н m}+m_{\text {ном. }}
$$

До роз'ємів відносять з'єднання частин агрегатів. Для фюзеляжу це з'єднання носової і хвостової частин з центральною, їх додаткова маса $m_{\text {раз }}=0,0667 m_{p \kappa}$. Додаткова маса з'єднань викликана необхідністю потовщення деталей і їх напустком, наближено ії приймають $m_{3 d}=0,1 m_{p к}$. Додаткову масу, пов'язану з неточністю виготовлення деталей $m_{н m}$ і обмеженою номенклатурою напівфабрикатів $m_{\text {ном }}$, визначимо за статистичними залежностями: $m_{н m}=0,05 m_{p \kappa}, m_{\text {ном }}=0,05 m_{p \kappa}$.

Додаткова маса, обумовлена конструктивно-технологічними чинниками, розподілена між носовою, центральною і хвостовою частинами фюзеляжу пропорційно площам їх поверхні.

Виходячи з отриманих значень мас частин фюзеляжу розраховані товщини умовної обшивки $\delta_{i} 3$ урахуванням конструктивно-технологічних чинників $\delta_{i}=m_{i} /\left(s_{i} \rho_{i}\right)$ і поверхневої густини конструкції $q_{i}=m_{i} / s_{i}$ кожної 3 частин. Результати розрахунків наведені в табл. 2 і показані на рис. 18, 19, 20. Поверхнева густина конструкції $q_{\kappa . i} \in$ критерієм масової ефрективності конструкції, що дозволяє оцінити інтенсивність навантажень, які сприймаються розглянутою частиною фююзеляжа, і можливість подальшого зниження ії маси.

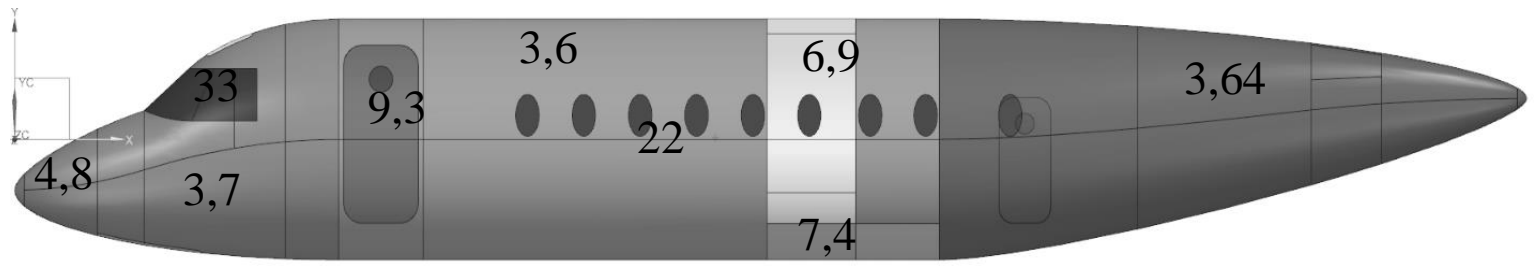

Рисунок 18 - Товщина умовної обшивки частин фюзеляжу

Для частин фюзеляжу з високою поверхневою густиною (скління кабіни пілотів, силовий пояс центральної частини фюзеляжу, двері, ніші шасі) доцільно проводити подальше уточнення розрахункових навантажень і оптимізацію конструкції. 
Таблиця 2 - Аналіз маси частин конструкції фюзеляжу

\begin{tabular}{|c|c|c|c|c|c|c|}
\hline $\mathrm{i}$ & $\begin{array}{c}\text { Частина } \\
\text { фюзеляжу }\end{array}$ & $\mathrm{m}_{\text {рк.і, }}, \mathrm{K} \Gamma$ & $\mathrm{m}_{\text {дк.i, }}, \mathrm{K} \Gamma$ & $\mathrm{m}_{\mathrm{i}, \mathrm{K}} \mathrm{K}$ & $\delta_{\mathrm{ki}, \mathrm{MM}}$ & $\begin{array}{l}q_{k i} \\
\mathrm{\kappa} / \mathrm{M}^{2}\end{array}$ \\
\hline 1 & Обтічник & $12.4(62 \%)$ & $7.5(38 \%)$ & $19.9(2 \%)$ & 4.82 & 8.68 \\
\hline 2 & НЧФ & $46.3(36 \%)$ & $84(64 \%)$ & $130.3(11 \%)$ & 3.66 & 9.89 \\
\hline 3 & $\begin{array}{l}\text { Скління } \\
\text { пілотів }\end{array}$ & $69(44 \%)$ & $86.3(56 \%)$ & $155.3(13 \%)$ & 33.8 & 84.4 \\
\hline 4 & Ніші шасі & $20(26 \%)$ & $55(74 \%)$ & $75.5(6 \%)$ & 7.35 & 19.80 \\
\hline 5 & Ілюмінатори & $36.5(47 \%)$ & $41.9(53 \%)$ & $78.4(6 \%)$ & 21.5 & 53.8 \\
\hline 6 & ЦЧФ & $190(55 \%)$ & $155(45 \%)$ & $345(28 \%)$ & 3.64 & 9.82 \\
\hline 7 & Силовий пояс ЦЧФ & $49.9(54 \%)$ & $42.5(46 \%)$ & $92.4(7 \%)$ & 6.94 & 18.70 \\
\hline 8 & Двері & $6.62(12 \%)$ & $50.4(88 \%)$ & $57(5 \%)$ & 9.27 & 25.00 \\
\hline 9 & XपФ & $131(46 \%)$ & 155 (54\%) & $286(13 \%)$ & 3.45 & 9.32 \\
\hline \multicolumn{2}{|c|}{ Фюзеляж в цілому } & $562(45 \%)$ & $678(55 \%)$ & 1240 & 4.83 & 13.05 \\
\hline \multicolumn{2}{|c|}{ НЧФ } & $133(42 \%)$ & $187(58 \%)$ & $320(26 \%)$ & 6.58 & 17.78 \\
\hline \multicolumn{2}{|c|}{ ЦЧФ } & $286(47 \%)$ & $324(53 \%)$ & $611(49 \%)$ & 4.89 & 13.22 \\
\hline \multicolumn{2}{|c|}{ XЧФ } & $142(46 \%)$ & 166 (54\%) & 309 (25\%) & 3.64 & 9.83 \\
\hline
\end{tabular}
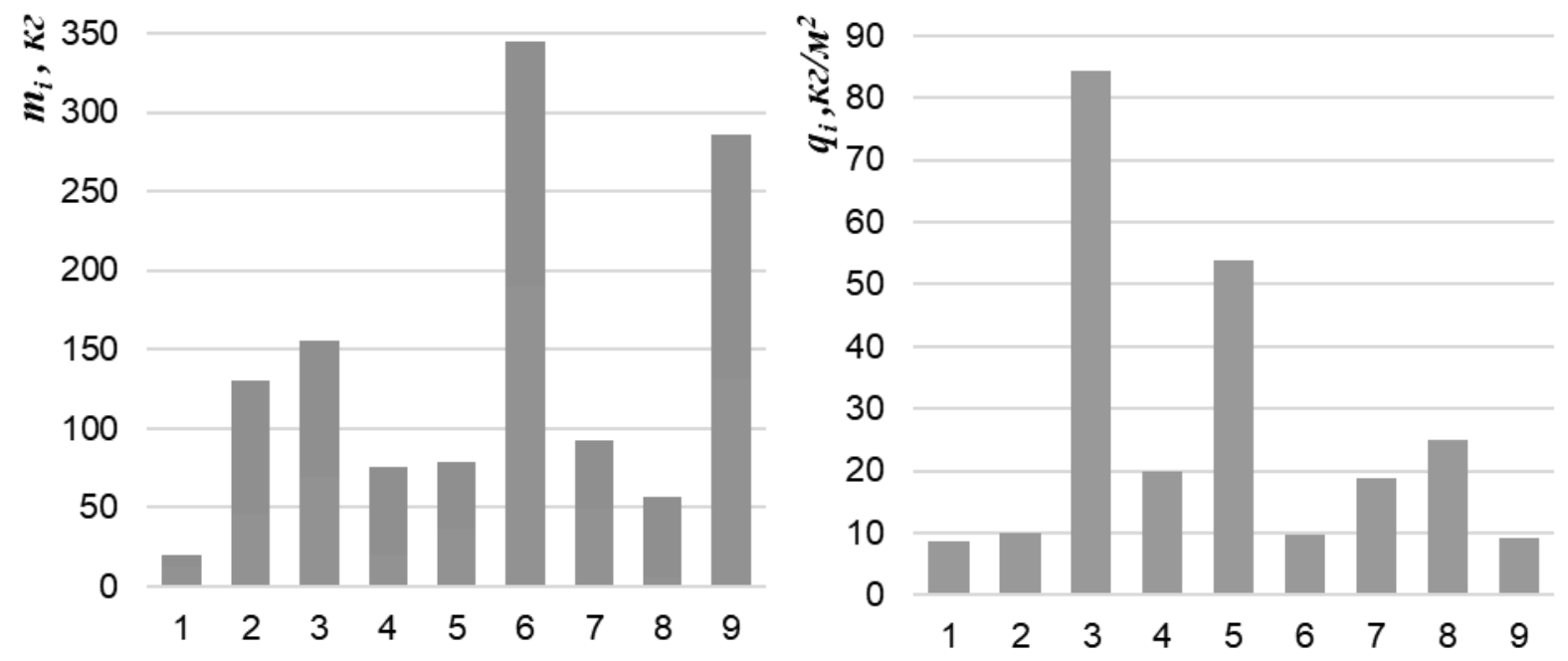

Рисунок 19 - Порівняльний аналіз маси регулярної конструкції, додаткової маси і поверхневої густини частин фрюзеляжу

(номера стовбців відповідають номеру частини фюзеляжу «і» згідно табл. 2)

Таким чином, розрахунок маси частин фюзеляжу відповідно до запропонованої методики дозволяє визначити величину і просторовий розподіл маси фрюзеляжу в другому наближенні.

Отримане значення маси фююзеляжу та ії̈ складових мало відрізняється від розрахованих за методикою В. А. Кисельова [7] і лежить у діапазоні мас, визначених за формулами першого наближення [6, 7] (В.М. Шейніна, О.А. Бадягіна і В.І. Козловського), що свідчить про достатню для методів другого наближення точність розрахунку. 


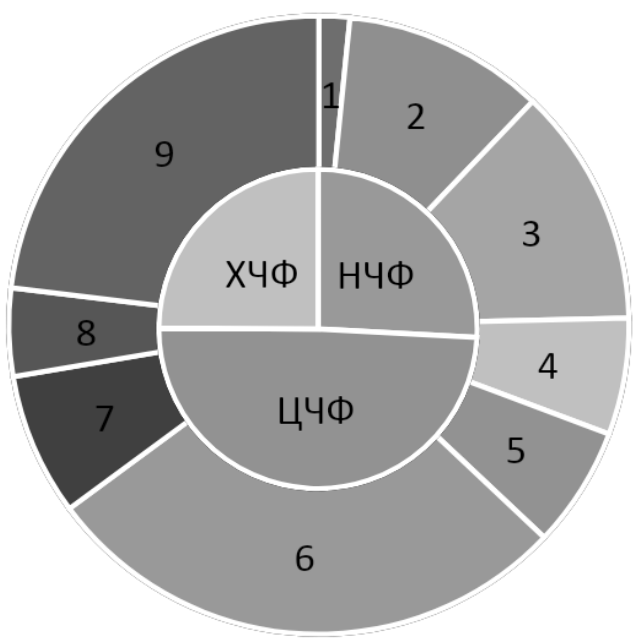

\begin{tabular}{|c|l|}
\hline $\mathrm{i}$ & Частина фюзеляжу \\
\hline 1 & Обтічник \\
\hline 2 & НЧФ \\
\hline 3 & Скління кабіни пілотів \\
\hline 4 & Ніші шасі \\
\hline 5 & Ілюмінатори \\
\hline 6 & ЦЧФ \\
\hline 7 & Силовий пояс ЦЧФ \\
\hline 8 & Двері \\
\hline 9 & ХЧФ \\
\hline
\end{tabular}

Рисунок 20 - Порівняльний аналіз мас частин фрюзеляжу

За наявності більш точних даних про маси прототипів доцільно уточнення коефіцієнтів вирізів і статистичних залежностей. Отримані значення мас частин фюзеляжу використано для проектування його конструкції.

Масо-інерційні характеристики узагальненої СкЕМ фрюзеляжу 3 урахуванням просторової конфігурації і властивостей конструкційних матеріалів його частин визначені за допомогою системи інтегрованого проектування Siemens NX.

Розрахунок зроблений поелементно згідно з відомими залежностями:

$$
x_{u, M}=\Sigma x_{i} m_{i} / m_{\phi} ; \quad y_{u, m}=\Sigma y_{i} m_{i} / m_{\phi} .
$$

На рис. 21 показано положення центру мас фюзеляжу, вікно виведення результатів містить значення моментів інерції і координати центру мас, кольором позначені матеріали частин фрюзеляжу.

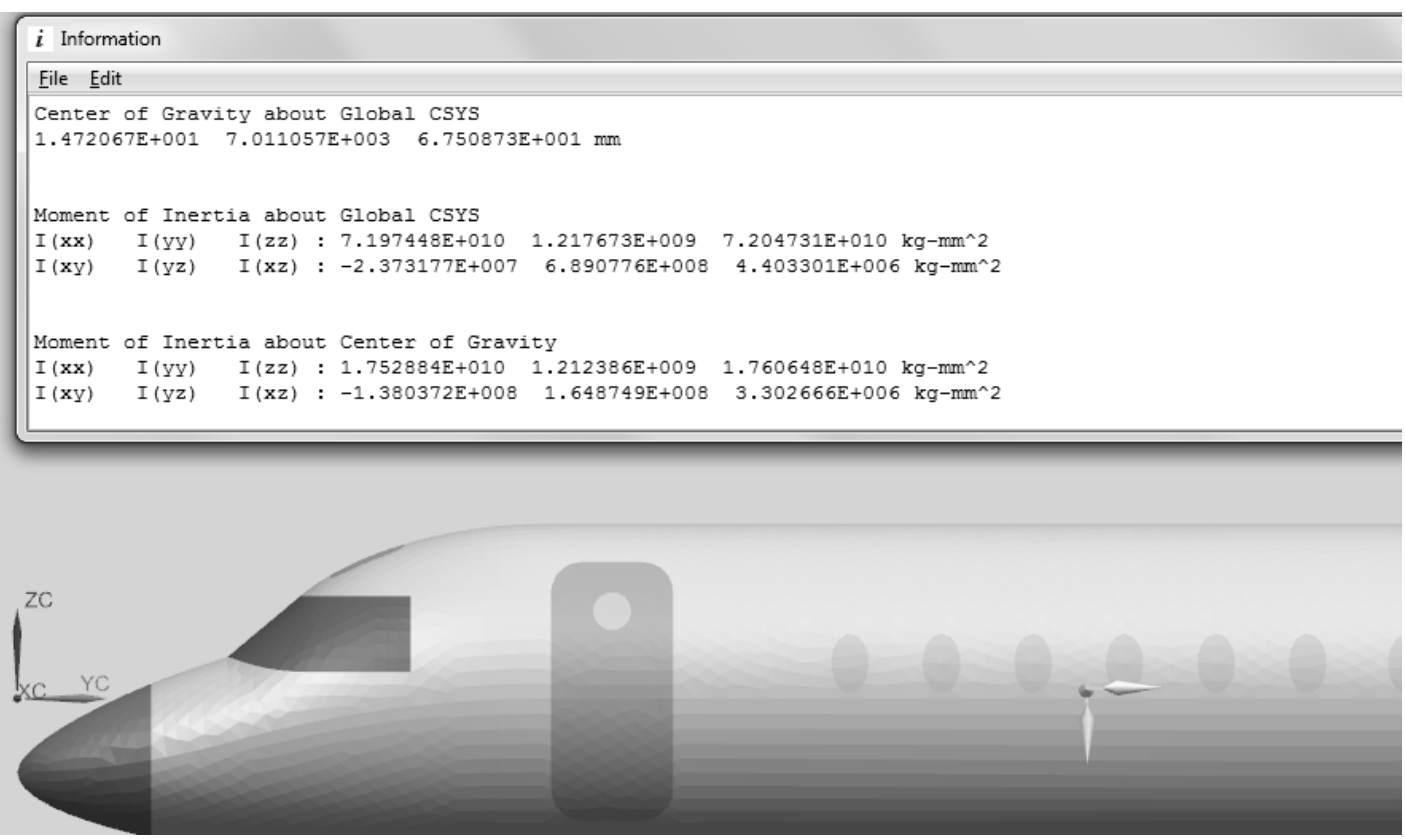

Рисунок 21 - Визначення положення центру мас і моментів інерції фюзеляжу 
Отримані масово-інерційні характеристики фююеляжу дозволяють уточнити інерційні навантаження в перехідних режимах польоту в процесі подальшого проектування літака.

\section{Висновки}

1. Запропоновано метод інтегрованого проектування носової частини фююзеляжу літаків транспортної категорії за допомогою комп'ютерних систем.

2. Проведено аналіз вимог нормативно-технічної документації, особливостей конструкції і методів проектування фюзеляжу літаків транспортної категорії та виявлено необхідність актуалізації методів проектування та розрахунку характеристик фююзеляжу з використанням параметричних моделей і систем інтегрованого проектування CAD/CAM/CAE/PLM. Сфрормульовано мету і задачі дослідження.

3. Розроблено і теоретично обґрунтовано метод інтегрованого проектування ЛТК. У рамках запропонованого методу створено параметричні моделі майстер-геометрії, аеродинамічного обтікання і масово-інерційних характеристик фюзеляжу з урахуванням особливостей конструкції ЛТК.

4. Запропонований метод використано для дослідження впливу геометричних параметрів НЧФ на аеродинамічні та масові характеристики фрюзеляжу ЛТК, відзначено оперативність роботи з параметричними моделями. Визначено раціональну конфігурацію ЛТК з урахуванням вимог щодо компонування і меж огляду з кабіни пілотів.

5. Обґрунтовано вибір параметрів НЧФ у попередньому і ескізному проектуванні перспективного літака для місцевих повітряних ліній, що дозволило впровадити і апробувати придатність запропонованого методу для використання у створенні нової конкурентоспроможної авіаційної техніки.

6. Використання методу інтегрованого проектування фюзеляжу для ЛМПЛ дозволило визначити раціональну конфігурацію НЧФ і підвищити паливну ефективність ЛМПЛ на 6,4\%, знизити аеродинамічний опір фюзеляжу на $10 \%$, збільшити кут огляду із кабіни пілотів ЛМПЛ на 10\% порівняно з конфігурацією попереднього проектування та забезпечити виконання вимог діючої НТД, а також визначити масово-інерційні характеристики фюзеляжу і його частин 3 урахуванням особливостей НЧФ і сформувати перелік обладнання кабіни пілотів, що забезпечить вимоги НТД щодо безпеки польоту ЛМПЛ 3 урахуванням особливостей умов експлуатації та можливостей його модифікації.

7. Розроблено конфрігурацію носової частини фюзеляжу літака для місцевих повітряних ліній, що дозволяє забезпечити сучасні вимоги щодо обладнання та компонування кабіни пілотів, низький хвильовий опір фюзеляжу та високу аеродинамічну якість і паливну ефективність на крейсерському режимі польоту зі швидкістю до 850 км/год $(\mathrm{M}=0,8)$.

8. У результаті апробації з використанням інших методів і параметрів існуючих літаків підтверджено точність результатів, отриманих із використанням запропонованого методу на рівні 5\%.

\section{Список літератури}

1. Гребеников, А. Г. Методология интегрированного проектирования и моделирования сборных самолетных конструкций / А. Г. Гребеников. - Харьков: ХАИ, 2006. - 532 с. 
2. Метод загального проектування регіональних пасажирських літаків / О.Г.Гребеніков, О.Д.Донець, С. В. Трубаєв, А. С. Чумак // Открытые информационные и компьютерные интегрированные технологии: сб. науч. тр. Нац. аэрокосм. ун-та им. Н.Е. Жуковского «Харьк. авиац. ин-т». - Вып. 85. Харьков, 2019. - C. 4 - 31. DOI: 10.32620/oikit.2019.85.01.

3. Нормы летной годности самолетов транспортной категории (АП25). - М.: МАK, 2009 - 322 c.

4. Certification Specifications and Acceptable Means of Compliance for Large Aeroplanes. - EASA, 2019 - 1135 c.

5. Кива, Д. С. Научные основы интегрированного проектирования самолетов транспортной категории: монография. В 3 ч. / Д. С. Кива, А. Г. Гребеников. - Харьков: ХАИ, 2014. - Ч. 2. - 326 с.

В. Ф. Мишин,

6. Проектирование самолетов: учеб. для вузов / С. М. Егер, Н. К. Лисейцев и др.; под ред. С. М. Егера. - 3-е изд., перераб. и доп. - М.: Машиностроение, 1983. - 616 с.

7. Шейнин, В. М. Весовое проектирование и эффективность пассажирских самолетов [Текст] : справочник / В. М. Шейнин , В. И. Козловский. - 2-е изд., перераб. и доп. - М.: Машиностроение, 1984. - 552 с.

8. Теория и практика проектирования пассажирских самолетов, Г. В Новожилов, - М.: Наука, 1976 - 439 с.

9. Информационные технологии в наукоемком машиностроении: компьютерное обеспечение индустриального бизнеса/ под. общ. ред. А. Г. Братухина. - Киев: Техніка, 2001. - 728 с.

10. Холявко, В. И. Расчет аэродинамических характеристик самолета. учеб. пособие в 2 ч. Ч. 1 / В. И. Холявко. - Харьков: ХАИ, 1991. - 72 с.

11. Торенбик, Э. Проектирование дозвуковых самолетов: / Э. Торенбик,

Е.П. Голубков, пер. с англ. - М.: Машиностроение, 1983. - 648 с.

12. Основи загального проектування літаків з газотурбінними двигунами: навч. посіб. / П. В. Балабуєв, С. А. Бичков, О. Г. Гребеніков та ін. - Харків: XАІ, 2015. -815 c.

\section{References}

1. Grebeny`kov, A. G. Metodology`ya y`ntegry rovannogo proekty' rovany’ya y’ modely’ rovany`ya sbornыx samoletnыx konstrukcy’j / A. G. Grebeny`kov. - Xar`kov: XAY', 2006. - 532 s.

2. Metod zagal`nogo proektuvannya regional`ny`x pasazhy`rs`ky`x litakiv / O. G. Grebenikov, O. D. Donecz', S. V. Trubayev, A. S. Chumak // Otkrыtыe y’nformacy`onnыe y’ komp`yuternыe y’ntegry 'rovannыe texnology 'y”: sb. nauch. tr. Nacz. aэrokosm. un-ta y`m. N.E. Zhukovskogo "Xar`k. avy`acz. y`n-t». - Vыp. 85. Xar`kov, 2019. - S. 4 - 31. DOI: 10.32620/oikit.2019.85.01.

3. Normy letnoj godnosty` samoleov transportnoj kategory`y`(AP-25).M.:MAK, 2009-322s.

4. Certification Specifications and Acceptable Means of Compliance for Large Aeroplanes. - EASA, 2019 - 1135 s.

5. Ky`va, D. S. Nauchnыe osnovы y`ntegry rovannogo proekty rovany`ya samoletov transportnoj kategory`y': monografy`ya. V 3 ch. / D. S. Ky va, A. G. Grebeny`kov. - Xar`kov: XAY`, 2014. - Ch. 2. - 326 s. 

My`shy`n,

6. Proekty`rovany`e samoletov: ucheb. dlya vuzov / S. M. Eger, V. F.

N. K. Ly`sejcev y` dr.; pod red. S. M. Egera. - 3-e y`zd., pererab. y` dop. - M.: Mashy`nostroeny`e, 1983. - 616 s.

7. Shejny`n, V. M. Vesovoe proekty`rovany`e y` effekty`vnost passazhy`rsky`x samoletov [Tekst] : spravochny`k / V. M. Shejny`n, V. Y'. Kozlovsky`j. - 2-e y`zd., pererab. y` dop. - M.: Mashy`nostroeny`e, 1984. - 552 s.

8. Teory ya y’ prakty`ka proekty’rovany`ya passazhy`rsky`x samoletov, G. V Novozhy lov, - M.: Nauka, 1976 - 439 s.

9. Y'nformacy`onnue texnology'y $v$ naukoemkom mashy`nostroeny'y`: komp`yuternoe obespecheny`e y`ndustry`al’nogo by`znesa/ pod. obshh. red. A. G. Bratuxy`na. - Ky`ev: Texnika, 2001. - $728 \mathrm{~s}$.

10. Xolyavko, V. Y`. Raschet aэrody`namy`chesky`x xaraktery`sty`k samoleta. ucheb. posoby`e v 2 ch. Ch. 1 / V. Y'. Xolyavko. - Xar`kov: XAY', 1991. - 72 s.

11. Torenby`k, Э. Proekty`rovany`e dozvukovыx samoletov: / E. Torenby`k, E.P. Golubkov, per. s angl. - M.: Mashy`nostroeny`e, 1983. - 648 s.

12. Osnovy zagal`nogo proektuvannya litakiv z gazoturbinny`my` dvy`gunamy: navch. posib./P.V. Balabuyev, S.A. By'chkov, O.G. Grebenikov ta in. - Xarkiv: XAI, 2015.-815 s.

Надійшло до редакції 12.04.2021. Розглянуто на редколегії 14.04.2021.

\section{Transport category airplane fuselage nose section integrated design method}

Regulatory and technical documentation, design features and methods of fuselage transport category aircraft design was performed and identified the need to update design methods and calculate the characteristics of the fuselage using parametric models and integrated design systems CAD / CAM / CAE / PLM. The method of integrated fuselage design of transport category aircraft is developed and theoretically substantiated. Within the framework of the proposed method, parametric models of master geometry, aerodynamic flow and mass-inertial characteristics of the fuselage were created, taking into account the design features of transport aircraft.

The proposed method was used to study the influence of geometric parameters of fuselage nose section on aerodynamic and mass characteristics of the fuselage, showing the efficiency of work with parametric models.

The choice of parameters of the fuselage nose section in preliminary and sketch design of a promising aircraft for local airlines is justified, which allowed to implement and test the suitability of the proposed method for in new competitive aircraft designing process.

The use of the method for integrated fuselage design for local aircraft allowed to determine the rational configuration of the nose section of the fuselage and increase the fuel efficiency of the aircraft by $6.4 \%$, reduce the aerodynamic drag of the fuselage by $10 \%$, increase the viewing angle from the cockpit by $10 \%$. and ensure compliance with current regulatory and technical documentation, as well as determine the mass-inertial characteristics of the fuselage and its parts and form a list of cockpit equipment that will meet flight safety requirements, taking into account the operating conditions and modifications of the aircraft.

The configuration of the nose section of the aircraft fuselage for local airlines has been developed, which allows to fit modern requirements for cockpit equipment 
and layout, low fuselage impedance and high aerodynamic quality and fuel efficiency in cruising mode at speeds up to $850 \mathrm{~km} / \mathrm{h}(\mathrm{M}=0,8)$. As a result of verification using other methods and parameters of existing aircraft, the accuracy of the results obtained using the proposed method at the level of $5 \%$ was confirmed.

Key words: transport category airplane; preliminary design; aerodynamics; mass calculation; fuselage parametric model; pilots' cabin, field of view, finite elements model.

\section{Відомості про авторів:}

Двейрін 0.3., кандидат технічних наук, доцент кафедри проектування літаків і вертольотів Національного аерокосмічного університету ім. М. $€$. Жуковського «XAl», заступник Генерального директора 3 проектування ДП «AНTOHOB».

Гребеніков О. Г., доктор технічних наук, профессор, профессор кафедри проектування літаків і вертольотів Національного аерокосмічного університету ім. М. Є. Жуковського «XAI». ORCID: 0000-0002-1509-0665

Гуменний А.М., кандидат технічних наук, доцент, завідувач кафедри проектування літаків і вертольотів Національного аерокосмічного університету ім. М. Є. Жуковського «XAI». ORCID: 0000-0003-1020-6304

Чумак А. С., кандидат технічних наук, ст. викл. кафедри проектування літаків і вертольотів Національного аерокосмічного університету ім. М. $€$. Жуковського «XAI». ORCID: 0000-0003-2913-7038 